\title{
Genealogical Position of Ugaritic: the Lexical Dimension Lexical Isoglosses Between Ugaritic and Canaanite *
}

\author{
Leonid Kogan ** \\ Russian State University for the Humanities, Moscow
}

The present contribution continues a series of publications by the author dealing with the lexical evidence for some of the much-discussed problems of the genealogical subgrouping of Semitic. In the present article, specific isoglosses between Ugaritic and the Canaanite languages (notably, Hebrew and Phoenician) are accumulated and discussed, their total number amounting to ca. 80 lexical items. In the second, concluding article (scheduled for publication in the forthcoming issue of Sefarad), this evidence will be compared with specific lexical isoglosses shared by Ugaritic with Semitic languages other than Canaanite.

KeYwords: Lexical Isoglosses; Basic Vocabulary; Ugaritic; Canaanite; Hebrew; Phoenician; Genealogical Classification of Semitic.

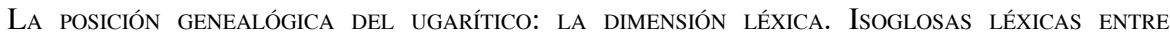
UGARÍTICO Y CANANEO. El presente artículo forma parte de una serie de publicaciones del autor dedicadas al factor léxico en la clasificación genealógica de las lenguas semíticas. Poco menos de 80 isoglosas exclusivas entre ugarítico y las lenguas cananeas (en particular, hebreo y fenicio), presentadas en el orden alfabético y acompañadas de una discusión general tanto lingüística como filológica, constituyen el núcleo del artículo, que va a ser complementado próximamente por un análisis detallado de posibles isoglosas léxicas entre la lengua ugarítica y las lenguas semíticas no pertenecientes al grupo cananeo.

PALABRAS ClAVE: isoglosas léxicas; vocabulario básico; ugarítico; cananeo; hebreo; fenicio; clasificación genealógica del semítico.

* It is a pleasant duty to thank Dennis Pardee for his critical reading of this study. The article was written in the framework of the projects 08-04-00465a (РГНФ/RFH) and 09-06-00153-a (РФФИ/RFBR). I am grateful to these institutions for their financial support.

\footnotetext{
***1kog@ rggu.ru
} 


\section{INTRODUCTION}

In an earlier publication by the present author (Kogan 2006a), an attempt was made to assess the relevance of the lexical data for the genealogical position of Ugaritic. More concretely, it was intended to use lexical evidence as a means of checking the validity of the hypothesis of the Canaanite affiliation of Ugaritic.

The analysis of the basic vocabulary from Swadesh wordlist did not yield any unambiguous result: ca. $70 \%$ of coincidences between Ugaritic and Hebrew look impressive at first sight, but most of this shared vocabulary belongs to trivial retentions from Proto-Semitic and is, consequently, of little value for genealogical classification. Certain or probable lexical innovations (semantic or formal) shared by Ugaritic and Hebrew proved to be extremely few.

However, it was clear from the very beginning that a conclusion obtained on the basis of Swadesh wordlist alone can only be very preliminary in the case of Ugaritic - a dead language with a restricted textual corpus. Not unexpectedly, those Ugaritic terms which are qualified as trivial retentions from PS are also those which are the best documented ones, whereas other, potentially more diagnostic semantic slots of Swadesh list are either vacant or occupied by philologically uncertain items. In such conditions, the necessity of broadening the scope of the lexical evidence was indispensable. The results of such a broader investigation, which takes into account the basic vocabulary of Ugaritic as a whole, are presented below to the reader's judgment. ${ }^{1}$

\section{Exclusive isoglosses between Ugaritic and CanaAnite languages ${ }^{2}$}

1. 'ibr 'a stocky male animal (bull, horse)' (DUL 10).

- The meaning 'bull' derives from the parallelism with $\underline{t} r$ 'bull' (1.12 I 3032 , II 53-55) and r'um 'aurochs' (1.10 III 20-21, 35-36). The meaning 'horse' is

${ }^{1}$ Due to the space limitations and for the reader's convenience, the data have been split into two contributions. The present one will deal exclusively with Ugaritic-Canaanite lexical features. In the second one, scheduled for the next issue of Sefarad, lexical features shared by Ugaritic with other Semitic languages will be presented, followed by general conclusions.

${ }^{2}$ In the presentation below, $\bullet$ will mark the philological section, which provides brief remarks on the attestations of the pertinent word in the Ugaritic corpus, will introduce exclusive cognates from Canaanite (or, in the corresponding sub-sections, Arabic, Aramaic and Akkadian), $\boldsymbol{\nabla}$ will mark the general discussion section. The only purpose of the philological section is to substantiate the meaning of the Ugaritic lexemes under scrutiny and the reliability of their textual attestation. Completeness of textual and bibliographic references has by no means been intended. 
probable for 1.14 III 16 (t'igt 'ibrh 'neighing? of his stallions'), since 'alp 'oxen' are mentioned in the following line $18 .^{3}$

- Eg.-syll. '"bi”ra 'stallion' (Hoch 1994:18), Hbr. 'abbīr 'bull; stallion' (HALOT 6). ${ }^{4}$

$\boldsymbol{\nabla}$ This animal name probably represents a substantivized adjective *'ab(b)ir'strong, mighty', attested in Hebrew as 'ābīr and 'abbīr (HALOT 6). The adjective, in its turn, may go back to the verbal root *' $b r$ 'to be strong, vigorous': Akk. abāru 'strength' (CAD $\mathrm{A}_{1}$ 38) and abru 'stark, kräftig' (AHw. 7), Arb. ' $b r$ 'to be in a good, right, proper state' (Lane 5), Amh. abrit 'conceit, vanity, arrogance; period of wealth; right, rule' (AED 1195), Cha. Eža abər, Enm. Gyt. abar, End. awər 'young person or animal in its prime' (EDG 9). See further Common Ethiopian *'br 'to be old': Gez. 'aber 'old woman', 'aberāwi 'old man, old woman' (CDG 5), Tgr. 'abbärä 'to be old, to grow old' (WTS 366), Zwy. ibīīi 'to be old', Wol. aber, Sel. abēr 'grandfather, grandmother' (EDG 9). ${ }^{5}$

2. 'abyn 'poor, wretch, insolvent' (DUL 14).

- The most reliable attestation of 'abyn is 1.17 I 16-19: 'abyn 'at [d]n'il mt $r p$ ' $i$ 'anh yzr hrnmy d 'in bn lh km 'ahh w šrš km 'aryh 'you are poor, oh Dn'il, the man of $r p^{\prime} u$, (you are) groaning, the valiant hrnmy, who has no son like his brothers, no descendant like his kinsmen'. ${ }^{6}$ Another possible case is 'abynm in 4.70:6, tentatively interpreted as "insolvent persons from a particular town” in KTU.

- Hbr. 'äbyōn (HALOT 5).

$\boldsymbol{\nabla}$ Notwithstanding von Soden's scepticism (1969:324), Common Canaanite $^{7} *^{*} V b y-\bar{a} n-{ }^{8}$ can be traced back — with a well-known semantic development

${ }^{3}$ But cf. SANMARTín 1978:350 ("Das Ug. gebrauchte ibr allerdings spezifisch für die Gattung 'Rind'...").

${ }^{4}$ Ps 50:13 (bəŝar 'abbììm 'bull meat'), Jer 8.16 (mișhălōt 'abbīrāw 'neighing of his horses').

${ }^{5}$ The meaning shift 'sturdy, strong' > 'old' may be less unusual than LesLau (CDG 5) believes (cf. BuCK 1949:959).

${ }^{6} \mathrm{KTU}$ 's reading 'abyn 'at is not universally accepted, but the alternative reading 'abynn does not contradict the identification of this form with the CC lexeme under scrutiny, cf. "dépouillé" in BordReUIL-PARDEe 2004:23, "Arm" in TropPer 2000:905 (but contrast "the lamenting of Dān'̄' ilu" in PARdeE 1997:344, "the longing of Daniel" in PARKer 1997:52).

7 "Common Canaanite" (hereafter CC) will be used as a designation of specific lexical isoglosses which Ugaritic shares with Hebrew and/or Phoenician. This purely technical label is not intended to anticipate the final conclusions about Canaanite or non-Canaanite affiliation of Ugaritic.

${ }^{8}$ As is well known, the earliest attested reflex of *'Vby-ān- is abiyannu in OB Akkadian texts from Mari (von Soden 1969:324-325, Durand 1998:450, STRECK 2000:83-84). 
(Buck 1949:782-784) — to the verbal root *'by 'to want, to desire' represented by Hbr. 'āba 'to want, be willing' (HALOT 3). ${ }^{9}$ The supposed Egyptian origin (< b'in 'bad') is not to be accepted (von Soden 1969:323, Muchiki 1999:236-237).

\section{3. 'dm 'to become red' (DUL 17).}

- Attested in 1.14 II 9 (trtḥs w t'adm) and 1.19 IV 42 ( $t^{\prime} i d d^{\prime} m$ b rlp ym). The meaning 'to rouge oneself' is widely accepted ('wash and rouge yourself' and "she rouged herself with "husk of the sea" in Pardee 1997:334, 355), although the supporting evidence is more etymological than contextual. ${ }^{10}$

- Hbr. 'ādōm 'red' (HALOT 15).

- Possible cognates of $\mathrm{CC}^{*}$ ' $d m$ 'to be red', extensively discussed in $\mathrm{Bu}$ lakh 2006:196-203, include Akk. adamu 'red"' (CAD A 95, AHw. 10, highly uncertain), Arb. 'dm 'être rouge, avoir la peau brunie', 'ādam- 'bruni, fauve, tirant sur le rouge' (BK 1 19, cf. Lane 37), Gez. 'addāmāwi 'red' (CDG 8). ${ }^{11}$ Since all these terms are quite marginal in the respective languages, ${ }^{*}$ ' $d m$ 'to be red' could represent a very important Canaanite-Ugaritic isogloss if the basic *' $d m$ in Ugaritic were demonstrable (which is, unfortunately, not the case, v. Kogan 2006a:449). ${ }^{12}$

4. 'adm 'man; mankind' (DUL 17).

- This lexeme is comparatively rare, but both individual and collective meanings are reliably attested: for the former v. 1.169:14-15 ( $l$ ' $a d m w d ~ h t m$ $l$ 'arș zrm l bn 'adm b 'anšt npțll 'Away from the man, he of the rod, depart

9 Traditionally connected with Arb. 'by, Min. 'by and Gez. 'abaya 'to refuse' (LANE 12, LM 1, CDG 6). As ingeniously observed by Nöldeke (1904:66), the Hebrew verb is almost always coupled with negative particles: $\boldsymbol{l} \overline{\boldsymbol{\sigma}}\left({ }^{\prime}\right)$ ' 'a $\bar{b} \bar{a}$ 'he did not want', etc. (for a strikingly similar structural parallel in Old Assyrian lā mu'ā'um 'not to want' see VeEnhof 1986). Nöldeke surmises that the original sense of Hbr. 'āb $\bar{a}$ was 'to refuse' (as in Arabic and Geez) and the negative particles were added to emphasize this negative meaning. This is hard to reconcile with the wide presence of ' $a b \bar{a}$ 'to want' in a variety of Arabic dialects, notably those of Southern Arabia (LANDBERG 1920:11-62, BeHNSTEDT 1992:5-6, DRS 3). With Landberg and contra Nöldeke, such forms can by no means be derived from the Classical $b \gamma y$ 'to want'.

${ }^{10}$ Note Pardee's reservations as far as the latter passage is concerned (1997:355).

${ }^{11}$ In BulaKh 2005:258 *' $d m$ is actually treated as the basic term for 'red' in Proto-Semitic (side by side with *lbn 'to be white', *tlm 'to be black' and *wrk 'to be yellow-green'), but the evidence supporting this claim is not very persuasive.

12 The same applies to the adjective *'admānu, attested syllabically as a field name. Its interpretation as 'red', although widely accepted (KüHNE 1974:162-163), is of necessity conjectural. 
to the Netherworld! Away from the human, in weakness be exorcised', Ford 2002b:155, 191-196), for the latter v. 1.14 I 36-37 ('il ... 'ab 'adm ' il ... father of mankind') and 1.3 II 7-8 (tmb̆s l'im h̆p y[ $m$ ] tṣmt 'adm ș'at špš 'she smote the people of the seashore, destroyed the men of the east').

- Pho. 'dm 'man, person, someone' (DNWSI 13-14), Hbr. 'ādām 'mankind; individual man' (HALOT 14).

$\boldsymbol{\nabla}$ The most transparent cognates of CC *'adam- are known from ESA (Sab. Min. Qat.), where ' $d m$ has a more specialized meaning 'servants, subjects' (SD 2, LM 1, LIQ 5) and functions as a suppletive plural of ' $b d$ 'servant' (Stein 2003:66). ${ }^{13}$ A more general collective meaning is present in Tgr. 'addam 'men, people' (WTS 384) and Tna. 'addam 'humanity, mankind, everybody' (TED 1530), perhaps contaminated with the proper name Adam (cf. Gez. 'addām, CDG 7). Note, finally, Arb. 'adam- 'skin' (Lane 36), which makes one think of Arb. bašar- 'skin; people' < PS *baŝar- 'meat, flesh' (SED I No. 41). ${ }^{14}$ CC *'adam- can thus be seen as a retention from PS *'adam- 'men, people', but still a rather specific one — note in particular the individual meaning 'man, person', unattested anywhere else in Semitic. ${ }^{15}$

5. 'adn 'lord, master; noble father' (DUL 18-19), 'udn '(place of) dominion' (ibid. 20), 'adt 'lady' (ibid. 23).

- The meaning 'lord' is widely attested in the poetic corpus (paralleled by $b^{\prime} l$ 'lord' in 1.2 I 17). The meaning 'father' is known from 1.24:33 ('adnh, paralleled by 'umh, 'ihh, 'ahtth), ${ }^{16}$ as well as from the lexical list (= Akk. $a b u$, Huehnergard 1987:48, 104).

- Pho. 'dn 'lord', 'dt 'lady' (DNWSI 15-16), Hbr. 'ādōn 'lord, master'

${ }^{13}$ For a semantic parallel cf. Russian люди 'people', formerly used as a collective designation of household servants (SRJa 8342 ).

${ }^{14}$ Bauer (1914) did not pay enough attention to the fact that, attractive as it is, comparison between 'adam- and bašar- does not yield any meaningful output from the viewpoint of historical semantics. In the case of bašar-, we are likely faced with two independent semantic developments from an original meaning 'flesh, meat' ('flesh' > 'skin' and 'flesh' > 'people'). As for 'adam-, no original meaning 'flesh' is available, and the hypothetic shift 'people' > 'skin' (or vice versa) is rather hard to imagine.

15 The individual meaning is qualified as "late and sporadic" for Hbr. 'ādām in HALOT, but seems to be common (maybe even the only one attested) for Phoenician/Punic ' $\mathrm{dm} / \mathrm{adom}$ (KRAHMALKov 2000:32-33).

16 A special meaning 'father' for 'adn is thus justified (contra Gzella 2007:531). Note, moreover, that according to PARDEE 2002:95 "In Ug. prose, 'adn normally designates the '(biological) father', not the '(political) father'," hence his translation 'to Yabnīnu, my father, say' for $l$ ybnn 'adny rgm in 2.64:1-3 (contrast 'to my lord' in DUL 19). 
(HALOT 13). Almost certainly unrelated is the logogram AD.DA.A.NI in the Amarna letters (Weippert 1974). Nab. 'dwnh and JdA 'dwn(h) (DNWSI 16, DJA 29) are likely borrowed from Canaanite in view of $-w$-. The same is true of Plm. 'dth 'lady' (DNWSI 16). ${ }^{17}$

$\boldsymbol{\nabla} \mathrm{CC} *$ 'adān-, competing with PS *ba l- 'lord', ${ }^{18}$ likely represents an extension of a Lallwort for 'father', still preserved in Ugr. as 'ad (DUL 15). ${ }^{19}$ In view of the wide presence of similar kinship terms in many languages of the world but, remarkably, not in Semitic ${ }^{20}$ — it is hard to decide whether the element *'adis an independent Canaanite formation or an early loanword from a non-Semitic source, cf. Hit. atta- (Friedrich 38), Hur. attai (Laroche 63), Sum. ad(.d a) (PSD $\mathrm{A}_{3}$ 9, with several orthographic variants). However, both the extension in $-\bar{a} n$ - and the meaning 'lord' must be regarded as CC innovations (Garbini 1984:94). ${ }^{21}$

6. 'adr 'wonderful, magnificent, strong, of good quality', 'udr 'nobility, the most noble' (DUL 20-22).

- Widely attested, the meaning 'to be wonderful, magnificent' is clear from the parallelism between 'udr and $m h \underline{m}$ d 'choice' in 1.4 V 16-17.

- Pho. ' $d r$ 'to be mighty, powerful', ' $d r$ 'great, mighty, grand, illustrious, splendid' (DNWSI 17-19), ${ }^{22} \mathrm{Hbr}$. ' $d r$ 'to be glorious', 'addī 'mighty, magnificent', 'ädär, 'addärät 'splendour' (HALOT 13-17).

${ }^{17}$ Rather uncertain, cf. HiLLERS-CUSSINI 1996:335.

${ }^{18}$ Exact details of the functional distribution between $* b a q$ - and *'adān- in Ugaritic and Canaanite remain to be investigated. The most ancient PS picture was probably identical to what is synchronically observed in Akkadian, where be lu is the only term for both 'lord, master' and 'owner' (CAD B 191). As I tried to show in Kogan 2005:532, in Aramaic *ba q- was relegated exclusively to the latter meaning since the earliest inscriptions on, the former one being expressed by $m r^{\prime}$. Is it possible to detect any similar distribution in Canaanite?

19 Attested in 1.23:32, 43 ('ad 'ad 'father, father!'), paralleled by 'um 'um 'mother, mother!' (v. Sanmartín 1977:272, 1991:170-171).

${ }^{20}$ Unless one follows Leslau, who wonders whether CC *'adān-is related to Tna. 'addä, Cha. Eža Muh. adot, Gyt. adōt, Enm. End. adōd, Sel. Wol. əndät 'mother' (TED 1529, EDG 18), Har. idōc 'woman' (EDH 19) - admitting at the same time that the Ethiopian terms are Cushitisms.

${ }^{21}$ Although one cannot exclude that *-ān- is due to an adaptation of the Hurrian determinate form attani (cf. SANMARTín 1977:271).

${ }^{22}$ The extraordinary wide attestation of the Phoenician adjective makes one suspect that it could be the main exponent of the basic concept 'big, large' in this language (cf. 'drnm w'd $s^{\text {' } r n m}$ 'from their large one to their small one' in KAI 85:1, pkšt 'drt 'large pyxis-vessels' in IEJ 35 83:4, 'trt ' $d r$ 't 'large crowns' in KAI 145 I 3) — at least a more suitable candidate than the otherwise expected $g d l$ or $r b$ (for which v. KRAHMALKov 2000:137 and 440 respectively). One cannot exclude that also in Ugaritic' $d r$ enjoyed the same basic status (see Section 3.1 of the forthcoming second part of this contribution). 
$\boldsymbol{\nabla}$ The origin of $\mathrm{CC}{ }^{*}$ ' $d r$ 'to be great, strong, magnificent' is uncertain. JPA 'dyr 'mighty' (DJPA 35) is marginally attested and (with Sokoloff) is most probably a Hebraism. JBA 'ădīrūta 'glory' is derived from the root $h d r$ with a weakening of $h$ in DJBA 81. Cf. perhaps Tna. 'addärä 'to heap up, amass, to collect' (TED 1530), which would point to PS *' $d r$ 'to be massive'. In DRS 10, $\mathrm{CC}{ }^{*}$ ' $d r$ is compared to Arb. 'udrat- 'scrotal hernia' (Lane 35). ${ }^{23}$

7. 'hb 'to love', 'ahbt 'love' (DUL 31).

- The meaning of 'ahbt is reliably derived from the parallelism with $d d$ 'love' (1.3 III 5-8) and yd 'love' (1.4 IV 38-39).

- Hbr. ' $h b$ 'to like, love', 'ahăbā 'love' (HALOT 17-18).

$\boldsymbol{\nabla}$ The origin of $\mathrm{CC} *$ ' $h b$ 'to love' is uncertain. The combination of ' and $h$ as root consonants, hardly possible in Semitic verbal roots (Greenberg 1950:168), makes one think of a secondary origin for one of the gutturals. An extension of the biconsonantal element *' $b$ 'to wish, to desire', represented by Hbr. 'by 'to want' (HALOT 3), $y^{\prime} b$ 'to long for' (ibid. 381), Syr. 'wb etpa. 'desiderio flagravit' (LSyr. 7), $y^{\prime} b$ 'desideravit' (ibid. 293), Arb. 'bb 'to yearn, long for' (Lane 3), is thus possible (with DRS 10). Cf., alternatively, Arb. $h b b$ 'to groan before copulation (a buck)' (LA 1 917), tentatively compared to Hbr. ' $h b$ in Zaborski 1971:65. The root *' $h b$ does not seem to be attested in Aramaic: the reading ' hbth in Cowl 75:3 is abandoned in favor of 'wpsth in Porten-Yardeni 1993:244, ${ }^{24}$ whereas JA 'ahăbā 'love' (Ja. 19) is poorly attested and must be borrowed from Hebrew.

8. 'amṣ 'strong' (DUL 74).

- Attested in 2.33:5 and 1.82:14. Both contexts are fragmentary, but the meaning '(to be) strong' is very likely ( $m l k n$ 'ams 'our king (is) strong', $y d k$ 'amṣ ['ammiș] 'strengthen your hand'). ${ }^{25}$

- Hbr. 'mṣ 'to be strong' (HALOT 65), 'ammiṣ 'strong' (ibid. 63).

$\boldsymbol{\nabla}$ The origin of CC *' $m s$ 'to be strong' is unclear. Cf. perhaps (with DRS 23) Arb. ' $m \underline{d}$ 'to be strongly resolved' (LA 7 128). It is also tempting to compare Akk. emēșu 'to be hungry' (CAD E 148, AHw. 214), with the meaning

23 "La rac. exprimerait la notion d'enflure".

${ }^{24}$ Cf. "the only time ' $h b$ is found in Ar. ??" (DNWSI 20).

${ }^{25}$ For the former passage v. PARDEE 2002:106. The translation "(may) your hand (be) strong" for the latter passage (DEL OLMO LETE 2004:376) is problematic since $y d$ 'hand' is feminine (cf. also the imperative 'uhd above in the same line). 
shift 'strong' > 'hardship, hunger' illustrated by Akk. dannatu 'hunger' < dannu 'hard, strong' (CAD D 87-92).

9. 'in 'there is not' (DUL 77).

- Widely attested (Tropper 2000:820-822).

- Pho. ynny, епnu 'there is not' (DNWSI 46), Moab. 'n id. (ibid.), Hbr. 'ayin, 'ên id. (BDB 34).

$\nabla$ There is no consensus about the etymology of CC *'ayn- 'there is not'. Comparison with the fossilized negative element 'on- in Geez (Leslau 1956:10, 1969:144, CDG 27) is problematic since *-ay-is not expected to be reduced to $\partial$ even in a heavily used non-accented proclitic. ${ }^{26}$ The phonologically transparent equation with Arb. 'ayna 'where' (HALOT 41) presupposes a semantic shift from rhetorical question to negation. ${ }^{27}$ If this etymology is accepted, the innovative nature of $C C^{*}$ 'ayn- is evident. Still another possibility is to identify *'ayna with the PS negative element *'ay/*' 1 (v. HALOT 38, CDG 1 for cognates), in which case the innovation (addition of $-n$ ) becomes formal rather than semantic (cf. Faber 1991:416). In any case, *'ayn- as a predicative element negating presence and existence ${ }^{28}$ is a highly specific $\mathrm{CC}$ lexical feature. ${ }^{29}$

10. 'an 'strength' (DUL 76).

- Hapax Legomenon ${ }^{30}$ in 1.6 I 50-52: dḳ 'anm l yrț ' $m$ bl l l y'db mrḥ

${ }^{26}$ The same is true of the hypothetic negative particle 'in in Arabic, where - $i$ - can scarcely go back to *-ay- (cf. LeSLAU 1969:137-140, with copious references to previous studies). Note that *-ay- $>-i$ - in this hypothetic lexeme is indeed codified as shortening in Fischer's standard reference grammar of Classical Arabic (2002:30).

${ }^{27}$ The same semantic development is usually thought to explain the emergence of Akk. yānu 'there is not', presumably from ayyānu 'where?' (CAD I/J 323, AHw. 411, GAG § 111b). If this derivation is correct, the Akkadian form, superficially similar to $\mathrm{CC} *$ 'ayn-, cannot be its immediate cognate (against most of our dictionaries and FABER 1991:414), but, at best, a result of a parallel semantic development. Indeed, the negative meaning of (ay)yānu does not seem to be attested before Middle Babylonian and, consequently, has no chances to be inherited from PS.

${ }^{28}$ The emergence of this feature probably correlates with the fact that Canaanite languages do not express the negation of existence by the fusion of *la and *yit tay (as against Aramaic, Arabic and Assyrian).

${ }^{29}$ Contra FABER $(1991: 421,423)$ who traces her * 'ayn 'isn't' back to PS.

${ }^{30}$ In this article, the definition Hapax Legomenon will be used technically in a broader sense, subsuming not only true unica, but also those Ugaritic words which are attested several times in the corpus, but only in one stereotype (or, more rarely, several quasi-stereotype) context(s). This convention will allow the reader to make a quick (albeit of necessity preliminary) distinction between common vocabulary and occasionalisms. 
'one of meager strength cannot run, or handle the lance with $B$ 'l' (cf. de Moor 1971:203, del Olmo Lete 1981:225, Parker 1997:154, Pardee 1997:269).

- Hbr. 'ōn 'power, wealth' (HALOT 22).

$\boldsymbol{\nabla}$ As suggested in BDB 19 (contrast DRS 12-13), CC *'ān- 'vigor, wealth' is probably related to Arb. ' $w n$ 'to be at ease, to enjoy a life of ease and tranquility; to be grave, steady, calm' (Lane 129). Gez. ta'ayyana 'to live well and comfortably' (CDG 50, LLA 797) evidently belongs to the same root.

11. 'un 'grief, misfortune' (DUL 78).

- Reliably attested in 1.5 VI 14-16: yșk 'mr 'un l r'išh 'pr plțt l ḳdḳdh 'he pours the ashes of grief on his head, dust of humiliation' on his skull'. More problematic is yṣly 'rpt b hm 'un in 1.19 I 39-41, possibly to be interpreted as 'he conjures the clouds in the terrible draught' (del Olmo Lete 1981:389, Parker 1997:68, cf. Renfroe 1992:80, Pardee 1997:351).

- Hbr. 'āwän 'disaster; sin, injustice' (HALOT 22), 'trouble, sorrow, wickedness' (BDB 19).

$\nabla$ As suggested in BDB 19 and DRS 12-13, CC *'awn- 'misfortune' may be related to Arb. ' $y n$ 'to be fatigued, tired' (Lane 138). Cf. perhaps Tna. 'into, 'inta 'curse, punishment; lack, deficiency; fault, error' (TED 1480).

12. 'any(t) 'ship' (DUL 85).

- Widely attested in letters and documents.

- Amarna Canaanite $a-n a-y i$ (as a gloss to GIŠ.MÁ in EA 245:28), Hbr. 'ŏnī 'fleet', 'ŏniyyā 'ship' (HALOT 71). It is uncertain whether i-ni-tum = HI-bi-tum in the lexical list An VIII 68 is a WS loanword with the meaning 'ship' as suggested in AHw. 382 (cf. CAD I 150 and CAD T 67).

$\nabla$ As is widely acknowledged (HALOT 70, CDG 410, Fronzaroli 19661967:212, 1971:627), CC *'Vny(-at)- ${ }^{31}$ 'ship' goes back to PS *'Vn(V)w- 'vessel, receptacle', represented by Akk. unūtu (AHw. 1422), Common Aramaic *mānā (LSyr. 373, Kogan 2005:528) and Arb. 'inā'- (Lane 119), to which Gez. nawāy (CDG 410) and Akk. nuwātu (AHw. 803, Huehnergard 1991a:692) may be further related. The meaning shift 'vessel' > 'ship', abundantly documented elsewhere

${ }^{31}$ There is no convincing explanation for the vocalic discrepancy in the first syllable, where $*_{-} a$ - in Ugaritic and EA is opposed to *- $u$ - in Hebrew. 
in the world's languages, ${ }^{32}$ would be exclusively Canaanite, but cf. Arb. $m \bar{n} \bar{n} \bar{a}-$ 'port' (LA 15 486) which can be plausibly derived from *mi-'nāw-. ${ }^{33}$

\section{3. 'apn 'wheel' (DUL 90).}

- Widely attested in economic texts, notably, in connection with $m r k b t$ 'chariot': tmn mrkbt dt 'rb bt mlk yd 'apnthn 'eight chariots assigned to the palace, together with their wheels' (4.145:1-3).

- Hbr. 'ōpan 'wheel' (HALOT 23). ${ }^{34}$

- CC *'Vpn- 'wheel' probably goes back to the verbal root *pny 'to turn' (Hbr. pāna, HALOT 937), with a well-attested semantic shift (Buck 1949:724725) and an (admittedly unusual) 'V-prefixation. Syr. 'opne 'wheels' (LSyr. 41), Hapax legomenon in Ez 10:13, is certainly a Hebraism.

14. 'aps 'extremity, edge, end' (DUL 91).

- Hapax Legomenon in 1.6 I 59-61, the meaning 'extremity' is reliably derived from the context ( $p^{\prime} n h l$ tmyyn hdm r'išh l ymyy 'apsh 'his feet do not reach the foot-stool, his head - its (upper) extremity').

- Amarna Canaanite up-si-hi 'extremity' (DNWSI 97), ${ }^{35}$ Pho. 'ps 'only' (ibid.), ${ }^{36} \mathrm{Hbr}$. 'äpäs 'extremity, end; end, nothing, nothingness; notwithstanding', 'ps 'to be at an end, to be no more' (HALOT 79), 'opsayim 'the two extremities' (BDB 67). ${ }^{37}$

$\boldsymbol{\nabla}$ As tentatively suggested in HALOT 79 (and more confidently in DRS 29), CC *'aps- 'extremity' may be borrowed from Akk. apsî 'cosmic subterra-

${ }^{32}$ For numerous Indo-European precedents v. Buck 1949:727. In Semitic, cf. Hbr. kal̄̄ 'vessel; ship, boat' (HALOT 479).

${ }^{33}$ For this interesting comparison, rarely mentioned in connection with Hbr. ’ŏnī, v. MAIZEL 1983:231.

${ }^{34}$ The form 'opnayim (Hapax Legomenon in Pr 25:11) is probably related to this lexeme: 'al'opnāw 'in proper circumstances' (= 'in its turn', “on its wheels”?).

${ }^{35}$ In EA 366:34, as a gloss to ZAG'.HI<.A>-ši (RAINEY 1978:34-35, 98). For a different evaluation of the EA evidence v. VAN SOLDT 1997, who prefers to relate up-sí- to Ugr. 'bs/'ps 'landmark, boundary' (DUL 174). Van Soldt is right to observe that the $u$-vocalism of the EA form is not easily compatible with the $a$-vocalism of Ugr. 'aps and Hbr. 'äpäs. This relevance of this argument is, however, to some extent undermined by Hbr. 'opsayim (v. fn. 37).

${ }^{36}$ Hapax Legomenon in KAI 26A IV 1-2 ('ps šm 'ztwd ykn l'lm 'only may the name of 'ztwd last for ever', GiBson 1982:52-53).

${ }^{37}$ Hapax Legomenon in Ez 47:3, where 'opsayim 'ankles' (= 'the extremities of the legs', cf. COOKE 1936:519) are opposed to birkayim 'knees' and motnayim 'hips' in v. 4. 
nean water' (CAD A $A_{2}$ 194), in its turn going back to Sum. a b zu (PSD A 2 184). If this hypothesis is correct, the borrowing is probably to be dated back to the CC period: while the fixed expression 'apsē 'äräs 'extremities of the earth' may be reminiscent of the mythological connotations of the Akkadian term, the more neutral meaning 'extremity, end', attested in both Ugaritic and Hebrew, does not seem to be attested in Akkadian and must be a Canaanite innovation.

15. 'urbt 'skylight, window' (DUL 99).

- The meaning 'window' is clear from $1.4 \mathrm{~V}$ 61-62, where 'urbt is paralleled by hln 'window' ( $b l$ 'ašt 'urbt b bh[tm] ḥln $b \mathrm{krb} h \mathrm{hklm}$ 'I will surely put a skylight in the house, a window in the palace') and 1.169:2-3 ( $w$ tṣ'u ... $k$ k țr 'urbtm 'it will go out ... like smoke through a skylight').

- Hbr. 'ărubbā 'hole in the wall through which the smoke passes' (HALOT 83).

$\nabla$ The origin of CC *'arubb-at- 'window' is obscure. It is tempting to connect it with the verbal root ' $r b$ 'to lie in ambush', well attested in Hebrew. ${ }^{38}$ Such a derivation implies an original basic meaning 'to spy, to lurk behind' (cf. in this sense Ja. 113, 116). ${ }^{39}$

16. ' $m s$ 'to load (with); to erect, build', ' $m s n$ 'load, cargo' (DUL 166), $m$ ' $m s$ 'the one loaded with' (ibid. 521).

- The meaning 'to load with' (rather than the more general 'to carry') is likely in $1.6 \mathrm{I} 12$ (' $\mathrm{ms} \mathrm{m}^{\prime}$ ' ly 'al'iyn $\mathrm{b}^{\prime} \mathrm{l}$ 'load on me, please, $B$ ' l, the Victorious One'), followed by $t \check{s}^{\prime} u$ 'al'iyn $b^{\prime} l \mathrm{l} k t p t$ ' $n t k t$ tsth 'she takes $B$ ' l, the Victorious One, and puts him on the shoulders of ' $n t$ '.

- Pho. 'ms 'to carry' (DNWSI 872), Hbr. 'ms 'to load (on to an animal); to carry' (HALOT 846).

$\boldsymbol{\nabla}$ From PS * 'ms 'to be massive, compact, heavy': JA 'ămas 'to press (the teeth together)' (Ja. 1090), Syr. 'ms (etpe.) 'contractus, condensatus fuit' (LSyr. 530), perhaps Arb. ' $m s$ 'to be hard, strong' (LA 6 177). ${ }^{40}$ Tgr. 'amsä 'to become pregnant' (WTS 456) may continue the meaning 'to be heavy' (Buck 1949:283), but can also be considered a semantic development from 'to carry'

${ }^{38}$ With RAINEY 1977:60, one hesitates to identify with this root the form $a r-b a-k u$ in TT 2:6, most probably a suffix conjugation form of Akk. erē bu 'to enter' (so most recently HorowitzOSHIMA 2006:133).

${ }^{39}$ Designations of window derived from the verb 'to look' (and similar) in Indo-European are discussed in Buck 1949:470.

${ }^{40}$ Not 'to be heavy' as in HALOT 846 (contrast BDB 770!). 
or 'to be loaded with' (Leslau 1956:40, Buck 1949:283-284). In this case, the meaning 'to carry' is not exclusively Canaanite.

17. 'p $\boldsymbol{p}$ 'pupil (of eye)' (DUL 173).

- The most reliable attestation is 1.14 VI 29-30: $d$ ' $k h^{\prime} i b$ ' $i k n n^{\prime} i$ ' $p$ ' $p h s p$ trml 'the pupils (of whose eyes) are of pure lapis-lazuli, whose eyes are like alabaster bowls' (translation from Pardee 1997:335). The meaning 'pupil' (or any other part of the eye) can hardly be deduced from this particular context, but cf. 'ašl $w$ b șp ' $n h$ 'I will repose in the gaze of her eyes' in the immediately following line of the parallel passage in 1.14 III 43-45. The context of ' $p$ ' $p k$ in RSOu $1453: 5^{\prime}$ is broken, but an anatomic meaning is likely in view of $p^{\prime} n k$ 'your feet' and $y d k$ 'your hands' in the next line.

- Hbr. 'ap'appayim 'eye-lashes; eyes' (HALOT 861).

$\boldsymbol{\nabla}$ The origin of CC * 'ap 'ap- 'part of the eye' is uncertain (cf. SED I No. 17), for a possible non-reduplicated cognate cf. Arb. 'af $\bar{a}$ '- 'a whiteness upon the black of the eye' (Lane 2094).

18. 'r 'city' (DUL 178).

- The most reliable attestations of ' $r$ 'city' are in the passages where it is

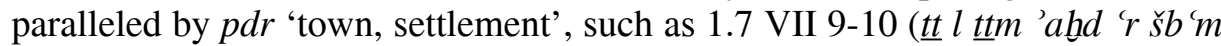
$\breve{s} b^{\prime} p d r$ 'he takes possession of sixty-six cities, seventy-seven towns'). ${ }^{41}$ Also probable are ' $r d \mathrm{kdm}$ 'the city of the East' in 1.100:62 (Pardee 1988:215) and ' $d$ $m \gamma y y b$ ' $r m$ 'until I come to the city' in 2.71:16-17 (Tropper 2000:766, contrast Pardee 2002:111).

- Pho. ' $r$ 'town' (DNWSI 883) ${ }^{42} \mathrm{Hbr}$. 'ir 'city, town' (HALOT 821).

$\nabla$ The only possible cognates of $\mathrm{CC} *$ 'i $r$ - 'city, town' are Sab. ' $r$ (pl. ' $\left.r r^{43}\right)$ 'mountain; citadel, hill-town' (SD 20), Qat. ' $r$ 'hill fortress, citadel' (LIQ 124). ${ }^{44}$ Comparison between Hbr. 'ir and Tgr. 'erä 'to come home, to turn in, to come' suggested in WTS 480 is rather far-fetched. For a critical assessment of the possible relationship between Hbr. 'ir and Sumerian u ru v.

${ }^{41}$ See also 1.16 VI 6-7 (' $r m t d ' u$... pdrm $t d$ ' $u$ 'she overflew' the cities, she overflew? the towns') and 1.14 III 6-7 (grnn 'rm šrn pdrm 'attack the cities, besiege the towns').

${ }^{42}$ Hapax Legomenon in KAI 37A 6 (lšrm b'r 'to those who dwell' in the city', cf. GiBson 1982:128). This interpretation is not universally accepted.

${ }^{43}$ A similar geminated root presumably underlies the plural form 'ārīm in Hebrew (cf. the Samaritan pronunciation 'arram, BЕN-ḦАYYIM 2000:248).

${ }^{44}$ The term is preserved in post-classical Yemeni Arabic as 'urr- 'Berg' (AL-Selwi 1987:150151), 'isolated mountain; rock, stone; fortified but not large stronghold' (Piamenta 320). The morphological shape of this term is quite different from that of Hbr. 'ir. 
recently Sommerfeld 2006:52-53. As is well known, the reflexes of CC $* i r$ in individual Canaanite languages differ with respect to their functional load (van Soldt 2005:182, Gzella 2007:536-537): while Hbr. 'ir is the basic term for city, town, the Ugaritic and Phoenician cognates are rather marginal, the corresponding basic terms going back to *kary-at-, *kar-t- (DUL 712, 715, DNWSI 1037)..$^{45}$

19. ‘sy 'to make, process, work' (DUL 190).

- Possible attestations of $\breve{s} y$ are subdivided into three groups in DUL. The expression $\check{s} d \check{s} y$, attested thrice in 4.282 , is interpreted as 'worked field'. The combination yn $\check{s} y$, attested in a broken context in $1.17 \mathrm{VI} 8$, is interpreted

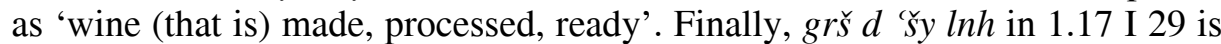
usually thought to mean 'driving out one who will do him (something bad)' (Pardee 1997:344). ${ }^{46}$

- Hbr. 'âŝa ‘ to do, make' (HALOT 889), Moab. ‘̌sy id. (DNWSI 890).

$\nabla$ Outside Ugaritic and Canaanite, comparable terms are only attested in ESA: Sab. Min. Qat. ' $s y$ 'to do' (SD 20, LM 16, LIQ 125). ${ }^{47}$ The highly marginal status of $\check{s} y$ in Ugaritic contrasts sharply with its basic status in Hebrew (and, presumably, Moabite). The main Ugaritic verb with the meaning 'to do, make' is $b^{l} l$ (DUL 205), ${ }^{48}$ undoubtedly related to Phoenician $p^{l} l$ (DNWSI 924), which is also the basic exponent of this meaning. ${ }^{49}$ As for $*{ }^{\prime} \hat{s} y / *(\check{s} y$, it does not seem to be at all attested in Phoenician.

${ }^{45}$ The Hebrew cognates kiryā and kërrät are, in their turn, comparatively rare poetic synonyms of $\operatorname{ir}$ (BDB 900).

46 An interesting semantic parallel to this semantic development ('to do' > 'to hurt') is provided by Mhr. fäl, Jib. fa 'ál 'to hurt someone' (ML 86, JL 51) <*pl 'to do'. Cf. also the meaning of the Tigre cognate in fn. 49.

47 The phonological irregularity (ESA $s_{1} \neq \mathrm{Hbr} . \hat{s}$ ) is remarkable and still awaits an explanation.

48 As D. Pardee points out to me in personal communication, there is no direct evidence that Ugr. $b^{\prime} l$ was indeed used with the general meaning 'to do' (= English to do, French faire): it is only the meaning 'to make, to produce, to manufacture' that is in evidence in all the extant passages. Pardee is right, moreover, that there is probably no diagnostic context for the general meaning 'to do' in the Ugaritic corpus available to us.

${ }^{49}$ Further cognates include Arb. $f l$ 'to do' (Lane 2420), Sab. $f l$ 'to make' (SD 43), Qat. $f l$ 'to make, to do' (LIQ 130), probably Tgr. fä 'alä 'to weave; to do mischief, to invent (lies)' (WTS 671, hardly an Arabism). For the MSA cognates with the meaning 'to hurt' v. fn. 46. In Aramaic * $p$ $l$ is only marginally attested, mostly with the meaning 'to work' (DJPA 441, LSyr. 585, DJBA 923, Kogan 2005:519). 
20. $\boldsymbol{b} \boldsymbol{d}$ 'into the hands of, (intended) for; from the hands of; at the hands of, for' (DUL 214).

- Widely attested (important observations on the available examples from various types of texts can be found in Tropper 2000:774-775, where the noncontracted combination $b y d$ is analyzed as well).

- Pho. $b d$ (Friedrich-Röllig 1999:33, 42, 181). CC *băad- 'by, at, from' seems to be lost in Biblical Hebrew, ${ }^{50}$ but its presence in an earlier stage of the development of Palestinian Canaanite is assured by $b a-d i-\hat{u}$ 'from his hand' as a gloss to Akk. $i$-na ŠU-ti-šu in EA 245:35 (Megiddo), v. Rainey 1996 III 23.

$\boldsymbol{\nabla} \mathrm{CC} * b \bar{a} d$ - 'by, at, from' is a fossilized combination of the preposition * $b i$ - and the substantive *yad- 'hand'. While structurally similar formations are well attested elsewhere in Semitic (e. g. Hbr. 'imm- $\bar{a} d-\overline{1}$ ' with me', Arb. 'in- $d a$ <* 'im-da, la-dā/la-day 'by', cf. Nöldeke 1910:116), formal and semantic peculiarities of *bă $d$ - provide a highly specific CC isogloss (cf. Garbini 1984:95).

21. $\boldsymbol{b} \mathbf{k}$ ' 'to search for, to look for; to investigate, find out' (DUL 235).

- Reliably attested in 1.6 IV 20 ('abkt 'alyn $b^{\prime} l$ 'I will look for $B^{\prime} l$ the

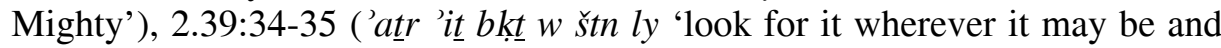
deliver it to me'), ${ }^{51} 2.42: 26$ ( $m l k n$ ybkt 'anyt 'our king is looking for ships').

- Pho. $b k \grave{s}$ 'to seek, to look for' (DNWSI 188), Hbr. bḳs (pi.) 'to search for, to demand' (HALOT 152).

$\boldsymbol{\nabla}$ The etymology of CC *bkt 'to look for' is not quite certain, but comparison with Jib. bókzót 'to dig away, to dig up, to dig for', bótkat 'to throw things around while searching' (JL 25, Müller 1995:145) and Tna. bäk $k^{w} \ddot{a} s \ddot{a}$ 'to pull up, to uproot (plants, trees)' (TED 1147, Brockelmann 1927:31) suggests a plausible semantic derivation from PS $* b k \underline{t}$ ' to dig (out)' ${ }^{52}$

22. brdl 'iron' (DUL 236).

- Hapax Legomenon in 4.91:6 ( $k \mathrm{krm}$ br $\underline{d l}$ 'two talents of iron').

- Pho. brzl (DNWSI 196), Hbr. barzäl 'iron' (HALOT 155).

${ }^{50}$ But note Job 17:16: $b d y$ (MT baddē) š'l trdnh ' $m$ yḥd ' l- 'pr nhtt 'Will it go down to Sheol with me? Shall we descend to the dust together?' (Pope 1965:128, with a penetrating comparative analysis on p. 131).

${ }^{51}$ For this problematic sentence v. PARDEE 2002:95 (contrast DUL 769 under spr 'bronze').

${ }_{52}$ Arb. bqt 'to mix, to mingle' (LA 2 134) cannot be related for semantic reasons, but cf. perhaps Arb. $\underline{t} q b$ 'to pierce, to penetrate; to be penetrating' (LANE 341) with metathesis. 
$\nabla$ CC *bardill- 'iron' belongs to a wider circle of Near Eastern designations of iron, such as Akk. parzillu 'iron' (CAD P 212, AHw. 837), ${ }^{53}$ Syr. parzlā id. (LSyr. 594), Arb. firzil- 'shackle, fetter' (TA 30 155), ${ }^{54}$ Sab. frzn 'iron' (SD 46, Sima 2000:325-328). However, none of these terms exhibits the same combination of root consonants (notably, the word-initial $b$-), which looks specifically Canaanite. ${ }^{55}$

\section{3. $\boldsymbol{d b r}$ 'to say' (DUL 264).}

- Attestations of $d b r$ are restricted to the letter 2.72:18-19 (tdbr 'umy l pn krt 'my mother will have to talk before the city', Bordreuil-Pardee 1991:144) and the incantation 1.82:8 ( $y \mathrm{dbr}$ trmt 'alm 'he says: my victuals are two rams', del Olmo Lete 2004:375). The noun $d b r$ 'matter, thing' is probably attested in the letters 2.71:13-15 ( $h t$ 'at $\mathrm{dbr} h m h \mathrm{~km} b l<b>k$ 'al tšt 'do not be worried on anything' ${ }^{56}$ ) and 2.32:8 ( $\mathrm{kl} \mathrm{dbrm} \mathrm{hmt} \mathrm{'all} \mathrm{these} \mathrm{matters',} \mathrm{context} \mathrm{broken).}$

- Pho. $d b r$ 'to speak', $d b r$ 'word' (DNWSI 238-239), Hbr. $d b r$ 'to speak', dābār 'word, matter' (HALOT 210-211).

$\boldsymbol{\nabla}$ Notwithstanding numerous attempts (v. references in BDB 180, HALOT 210, DRS 214-215, Schmidt 1978:94-95), no convincing etymology for $\mathrm{CC} * d b r$ 'to speak' has been proposed so far. The root $d b r$ with this meaning is not attested in Aramaic beyond the preposition ' $l$-dbr, 'al-dibrat 'on account of', which, as plausibly suggested in HALOT 1848, must be borrowed "from Canaanite formal language". For the presence of $d b r$ in the Deir Alla inscription (II.7) and its implications for the genealogical setting of its language v. Kogan 2005:553-554. There is hardly any direct relationship between CC *dbr and Arb. dabbara 'to consider, forecast the results of the affair; to meditate upon' and 'to relate the tradition received from another person' (Lane 844), as both meanings look like internal Arabic developments from 'to follow' - the basic meaning of $d b r$ in that language. The functional load of Ugr. $d b r$ is inferior to that of its cognates in Hebrew and Phoenician, where it functions as the main exponent of the meaning 'to speak' (covered by rgm in Ugaritic, Kogan 2006a:455).

${ }^{53}$ Numerous syllabic spellings with PA can be found in ReITER 1997:361-368. Since BAR is the normal rendering of [par] (= pár) in Old Assyrian (vON SoDEN-RöLLIG 1991:10), I can only wonder why "the Old Assyrian form of the word for 'iron' ... and the local West-Semitic forms ... have an obvious common feature: the initial pronunciation with |b|" (ARTZI 1969:270).

${ }^{54}$ Also: 'scissors by which iron is cut by a blacksmith'.

${ }^{55}$ It is interesting to observe that other phonetic variants are not attested in the Canaanite milieu: Garbini's attempt to identify prāzzōn in Jud 5:7 with Sab. frzn (GARBINI 1978) is, contra Sima 2000:327, to be rejected (Kogan-Korotaev 2003:110-111).

${ }^{56}$ With Tropper 2000:243, PARdeE 2002:111. 
24. dgn 'grain, wheat' (DUL 267).

- Hapax Legomenon in 1.16 III 13-14: nš u r'iš hrțtm l țr 'bd dgn 'the ploughmen lifted their heads, on high those who work the grain' (Pardee 1997:341).

- Pho. dgn 'grain' (DNWSI 241), Hbr. dāgān ‘corn, grain' (HALOT 214).

$\boldsymbol{\nabla}$ The origin of CC *dagan- 'grain' (in particular, its relationship to the theonym *Dagă $n$ ) is obscure, v. Renfroe 1992:91-94, del Olmo Lete 2001, Schwemer 2001:282. Attestations of *dagan- in Aramaic are sporadic ${ }^{57}$ and probably due to Canaanite influence.

25. gg 'roof' (DUL 296).

- Reliably attested, the clearest evidence for the meaning 'roof' comes from 1.14 II 26-27 ( $w$ yrd krt l ggt ' $K r t$ will descend from the roof').

- Amarna Canaanite ga-ag-gi-m[i] (EA 287:37, as a gloss to ú-ri-e, CAD G 9), Hbr. $g \bar{a} g$ (pl. gaggōt) 'roof' (HALOT 176).

$\boldsymbol{\nabla}$ The origin of CC * gagg- 'roof' (Greenfield 1969:98, Ginsberg 1970:103) is unclear, etymological comparisons suggested so far carry little conviction. ${ }^{58}$

26. $\boldsymbol{g} \boldsymbol{l}$ 'to rejoice' (DUL 297).

- Hapax Legomenon in 1.16 I 14-15, the meaning is clear from the parallelism with šmb̆ 'to rejoice' ( $b$ hyk 'abn n'šmb b l mtk ngln 'we are glad, our father, in your life, in your immortality we rejoice').

- Amm. $g l$ 'to rejoice' (DNWSI 222), ${ }^{59} \mathrm{Hbr} . g y l$ 'shout in exultation, rejoice' (HALOT 189).

${ }^{57}$ Egyptian Aramaic dgn (Hapax Legomenon in Ahiqar, Porten-YARDENI 1993:XXX), JPA dgn (DJPA 139).

${ }^{58}$ Thus, a borrowing from Egyptian $\underline{d} 3 \underline{d} 3$ advocated in KOEHLER 1940:37-38 is only conceivable for a very early, prehistoric date when proto-Afroasiatic $* g$ was not yet (fully) palatalized in Egyptian (cf. VeRGOTE 1945:34-36) - the normal Canaanite renderings of Egyptian $\underline{d}$ are of course $s$ or $t / t$ (MuchiKi 1999:263), as in șī 'ship' < $\underline{d} 3 y$, tabba 'at 'signet-ring' < $\underline{d} b$ '.t and $t \bar{e} b \bar{a}$ 'ark' < $\underline{d} b 3 . t$ (let alone the fact that the common meaning of Egyptian $\underline{d} 3 \underline{d} 3$ is 'head' whereas 'Dach eines Baumwerks' looks like a late occasionalism, Wb. 5 531). Gez. gag 'pillory, shackle, fetter, chain' (CDG 184) can hardly have anything to do with Hbr. gāg (contra LLA 1206). Comparison with gožžo 'hut, booth', widely attested throughout Modern Ethiopian (EDG 270) would be more attractive, but this word is thought to be borrowed from Cushitic (BROCKELMANN 1950:19).

${ }^{59}$ For the context ( $y g l$ wyšm ̣̣ bywmt rbm wbšnt rḥkt 'may he rejoice and be happy for many days and in years far off', Tell Siran 6-8) v. JACKSON 1982:36. 
$\nabla \mathrm{CC} * g y l$ 'to rejoice' is probably derived from PS * $g w l / * g y l$ 'to move in circle, to turn, to dance' (cf. Nöldeke 1904:43, Leslau 1956:16, DRS 108): pB. Hbr. gyl 'to form a circle' (Ja. 238), Arb. ̌̌wl 'to go round' (Lane 488), Tgr. goyla 'dance', gola 'to dance (and sing)' (WTS 591), Tna. $g^{w}$ ayla 'a traditional dance beginning with the participants forming a circle' (TED 2352), Jib. egtél 'to wander, tour around' (JL 80).

27. grš 'to eject, to drive out, to evict, to cast out' (DUL 310).

- Widely attested in myths, epics and incantations. Remarkable is one non-literary example: $k m$ 'agrškm b bty ksp hmšm 'is' 'if I expel you from my house, I will pay fifty (shekels of silver)' (3.9:6-10). For the neutral meaning 'to send' see now RS 94.2284:22-23: w grš bn'il w ykḥ t'nk 'et (quand) Bana'ilu est renvoyé, il prendra ta réponse' (Bordreuil-Pardee 2004:97-98). ${ }^{60}$

- Hbr. grš (mostly pi.) 'to drive out' (HALOT 204), Moab. grš 'to drive away' (DNWSI 236). The hypothetic Phoenician attestation of this root (ngřs in KAI 46:2) is not universally accepted (cf. DNWSI 236, Krahmalkov 2000:144).

$\nabla$ Ginsberg (1970:103) adduces CC *grš 'to drive out' as a root “confined to the Canaanite languages", which is not quite correct in view of Syr. graš 'traxit', pa. 'sustulit, abstulit, attulit' (LSyr. 135). The prominence of * grš 'to cast out, to expel' in Canaanite is nevertheless conspicuous (note that the Syriac verb, strangely missing from the list of cognates in HALOT 204 , is sparsely attested, ${ }^{61}$ whereas its semantic overlap with CC * grš is not complete ${ }^{62}$ ), and it is tempting to suppose that this meaning represents a shared innovation from an original (and more general) 'to drive (away)', further represented by Arb. ̌̌arīsat- 'cattle stolen away' (TA 15 495). ${ }^{63} \mathrm{Mhr}$. gərō $\hat{\text {, }}$ Jib. gérós 'to drag, to pull, to push' (ML 125, JL 79) are hard to separate from this root (with Leslau 1956:16), but MSA $\hat{s}$ does not regularly correspond to either Hbr. $\check{s}^{64}$ or Syr. $\check{s}$ or Arb. $s$. One cannot exclude, finally, that this root was also present in Sargonic Akkadian. ${ }^{65}$

${ }^{60}$ Reference courtesy Dennis Pardee.

${ }^{61}$ But note its extraordinary wide presence in Turoyo (RITTER 1990:178-180), which definitely excludes an otherwise feasible possibility of a literary Hebraism in Syriac.

${ }^{62}$ The Common Aramaic semantic equivalent of CC * grš is of course *trd (HALOT 1886).

${ }^{63}$ Perhaps also క̌rs II 'to expose so. to people's attention' (ibid.), interpreted as “promener dans les rues (p. ex. un criminel avant le supplice)" in BK 1279. I fail to locate in the traditional lexicography any reference to mažras- 'pâturage', mentioned with no source in DRS 197.

${ }^{64}$ Which, of course, depends exclusively on the Masoretic pointing.

65 Thus, Bonechi (1997:481) refers to GELB 1957:120 where [a]-dì la tág-ru-「śa -am 'before you come' from the Sargonic letter Ad 12:14 is discussed. One more Sargonic attestation of this 
28. gšm 'rain, downpour' (DUL 310).

- Hapax Legomenon in 2.38:11-14 ('anyk dt l'ikt mṣrm hndt b șr mtt by $g \check{s} m$ 'adr). This difficult passage has been repeatedly discussed, ${ }^{66}$ but the meaning 'storm, tempest' for $g \check{s} m$ is not in doubt.

\author{
- Eg.-syll. gas"mu 'storm' (Hoch 1994:354), ${ }^{67}$ Hbr. gäšäm 'rain' (HA- \\ LOT 205). ${ }^{68}$
}

verb is in the royal inscription of Naram-Sin: LUGAL.AN.NÉ [i]g-ru-sa-am 'PN came' (RIME 2.1.4.7:7). Given the fact that Hbr. gřs is mostly attested in the intensive stem, the non-active meaning of the Akkadian verb (presumably, 'to go away' and, with the ventive ending, 'to come here') does not offer any problem. Note, finally, the enigmatic expression a-na ga-ra-śi-im iś-kùn, attested passim in the inscriptions of Rīmuš (v. references in KIENAST 1994:228) and plausibly interpreted by W. Sommerfeld (p. c.) as 'he expelled, he drove away' (by far superior to the traditional "ins Lager verlegt hat").

${ }^{66} \mathrm{~V}$. references in WATSON 2002:795-796 and a balanced rendering 'your ships that you dispatched to Egypt were wrecked near Tyre when they found themselves caught in a bad storm' in PARDEE 2002:94.

${ }^{67}$ Not universally accepted, cf. RAINEY 1998:450, WoODHOUSE 2003:281.

68 The Hebrew and Ugaritic terms, though obviously cognates, are not equivalent from the functional point of view. The Ugaritic word was probably rare and did not function as the general designation of rain ("pas seulement une forte pluie ou une 'pluie torrentielle' mais plutôt une 'tornade"”, BordreuIL 1991:29). The main Ugaritic designation of rain was likely $m$ tr (Kogan 2006a:447). In Hebrew, gä̌s̆m has become prominent as the basic exponent of the meaning 'rain', to some extent depriving $m \bar{a} t \bar{a} a$ of this function. However, this process was by no means completed: $m \bar{a} t \bar{a} r$ is still so widely used that it is hard to decide which of the two terms synchronically occupies the basic semantic slot for the concept 'rain'. Zobel (1997:251) believes that 'the most general term for rain' is $m \bar{a} t \bar{a} r$, but provides no substantiation for this opinion. Absolute frequency being nearly identical (38 attestations for $m \bar{a} t \bar{a} r$ vs. 35 for gäsäm, ZoBel 1997:250), it would be tempting to suppose that māțār was more "poetic" and gäšäm more "prosaic", but at least statistically this is not the case (ca. 13 prosaic attestations for each term). There may be, however, a few more subtle arguments in favor of the basic status of gäs̆äm. In the prosaic passages, gä̌s̆am is found in a variety of contexts with meteorological connotations: rain and rainbow (Ez 1:28), rain and dark heaven, clouds and wind (1K 18:45), rain and wind (2K 3:17), sound of rushing rain (Ez 34:26), rain and storm-wind (Ez 13:11). In prosaic passages involving $m \bar{a} t \bar{a} r$ such combinations are less common (cf. rain, hail and thunder in Ex 9:33-34, rain and thunder in 1S 12:17-18). Much more frequently, prosaic passages mentioning mātā $r$ deal with presence/absence of rain as the source of fertility. In the poetic corpus, the distribution is slightly less pronounced: contrast gä̌s̆m and wind (Pr 25:14), gäšäm and northern wind (Pr 25:23), gäs̆äm and clouds (Qoh 11:3, 12:2), g ä̌s̈äm and autumn (Ct 2:11) with māțār and lightening (Ps 135:7, Je 10:13), mātāar and clouds (Is 5:6). Can one surmise that in spoken Hebrew gä̌äm was the main term for rain as a meteorological phenomenon, whereas mätär was more connected with rain water flowing on the ground, primarily as a source of fertility? The fact that $y r d$ 'to go down (rain from the heaven)' is more frequent with reference to gäšäm (Ez 34:26, Is 55:10, Jo 2:23) than with reference to $m \bar{a} t \bar{t} \bar{r}$ (Ps 72:6) might point in the same direction. 
$\boldsymbol{\nabla}$ The origin of CC * ${ }^{\prime} g \mathrm{~V} \check{s} m$ - 'rain' is uncertain. According to the widely accepted etymology (HALOT 205, DRS 196), it is metathetically related to Syr. šegmē d-mețā 'magni imbres' (LSyr. 755) and Arb. š̌m 'to pour water, to rain' (Lane 1312). Any connection with Tna. gässämä 'to drink a lot, to quench one's thirst' (TED 2280)?

29. $\boldsymbol{g t}$ 'wine or olive press', 'farmstead, estate' (DUL 310).

- The presumably original meaning 'olive press' does not seem to be attested in the Ugaritic corpus (Michaut-Colombot 1997:579-580). In 3.5:5-10,

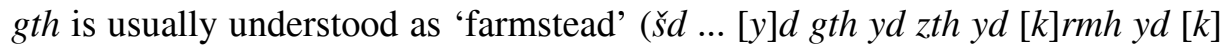
$l k l h$ 'the field ... with its farmstead, its olive-groves, its vineyards and everything else'). The same is likely for $g t t$ in RSOu 1435 II 35. ${ }^{69}$ Elsewhere, $g t$ is only attested as the first element of toponyms (DUL 311-313). For a comprehensive description of $g t$ as an economic institution v. Heltzer 1982:48-79.

- Hbr. gat 'wine-press' (HALOT 206).

$\boldsymbol{\nabla}$ The etymology of CC * gin-t- 70 'wine or olive press' is uncertain. The traditional derivation from a non-attested * ygn is morphologically attractive, but Arb. $w \breve{n} n$ 'to beat (usually about clothes beaten by a fuller)' (LA 13 548-549) is semantically too remote to be a reliable cognate (cf. BDB 387, HALOT 206, DRS 493-494). Alternative etymologies as formulated in Michaux-Colombot 1997 are difficult to accept (Heltzer 1999:196-197). ${ }^{71}$

30. $\boldsymbol{h l m}$ 'to hit' (DUL 339).

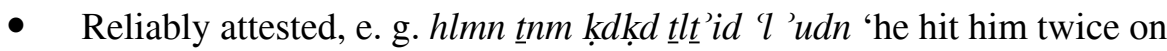
the crown, thrice on the ear' (1.18 IV 22-23).

- Hbr. $h l m$ 'to strike, to beat' (HALOT 249), Pho. mhlm 'struck coinage, coin mint' (Krahmalkov 2000:272, cf. DNWSI 601).

$\boldsymbol{\nabla}$ There is no reliable cognate for CC *hlm 'to hit, to strike'. Cf. perhaps

69 "Les hameaux, des fermes fortifiées ( $g t$ en ougaritique correspond à dimtu en accadien" (BordReull-PardeE 2001:351).

${ }^{70}$ This vocalization is suggested by syllabic spellings of Canaanite toponyms. In Hebrew, the phonetic shift * gin-t- > gat is identical to one observed in *bin-t- > bat 'daughter'.

${ }^{71}$ The very idea (somewhat clumsily expressed throughout Michaux-Colombot's article) of regarding *gin- $t$ - as a by-form of *ginn-at- $/$ *gann-at- 'garden' (a feminine formation from *ginn$/ * g a n n-)$ is not unattractive: note that $* g V n n$-at- is otherwise unattested in Ugaritic, whereas in Hebrew *-at-l*-t-doublets like kiryā/kää̈t 'town' are commonplace. However, the hypothetic semantic narrowing from 'garden, agricultural estate' to 'vat, wine-press' ("la gat- 'pressoir' ne serait qu'un sens secondaire à la gat- 'surface délimitée'”) is rather hard to imagine. 
(with Leslau 1956:18 and DRS 417) Tna. halämä 'to smack s. o. in the face, to box his ears' (TED 4).

\section{1. hmlt 'multitude' (DUL 342).}

- Reliably attested in parallelism with $n s ̌ m$ and l'im 'people' in 1.3 III 27-28 ( rgm l td' nšm w l tbn hmlt 'arș 'a matter which people do not know, the multitudes of the land do not understand'), 1.6 I 6-7 (b'l mt my l'im bn dgn my $h m l t$ ' $B$ ' l has died, what (will happen to the) people? Dgn's son — what (will happen to the) multitude?'), 1.6 II 17-19 (npš hsrt bn nšm npš hmlt 'arṣ 'my appetite lacked men, my appetite - the multitudes of the earth'). Less decisive is 1.2 I 18 (tn 'ilm d tḳh d tkyn hmlt 'give (up), o gods, the one whom you obey, the one whom the hordes (of the earth) fear'). ${ }^{72}$

- Hbr. hămulla 'crowd' (HALOT 251).

$\nabla$ As suggested in DRS 419, CC *hamull-at- 'crowd' is probably an extension of the widely attested biconsonantal element $* h m$ 'to be noisy' (the semantic shift is well known from Hbr. hāmōn 'turmoil, noise, roar; multitude, crowd', HALOT 250). Old Aramaic hml 'noise' in KAI 222A 29, often compared to Hbr. hămullä (e. g., DRS 423), is unreliable and eventually rejected in DNWSI 287 (contrast Fitzmyer 1995:87). Arb. hml 'to overflow and pour forth (water, rain)' (LA 11 848, Lane 3045) compared in HALOT 251 is semantically remote. ${ }^{73}$

32. $\boldsymbol{h r}$ 'mountain' (HALOT 345).

- Reliable attestations are restricted to the incantation 1.107, where $\mathrm{hrm}$ occur in the phrase 'isp [šp] ̌s l hrm $\gamma r p l$ 'remove, $\breve{S} p \check{s}$, the clouds from the mountains' (1. 44 and elsewhere). The meaning 'mountains' for $\mathrm{hrm}$ in this passage is widely accepted (Pardee 1988:249, del Olmo Lete 2004:372-373). ${ }^{74}$

- Eg.-syll. ha`ru 2 (Hoch 1994:213-215), Amarna Canaanite ha-ar-ri (as

72 Translation adapted from PARDEE 1997:246 (cf. PARKER 1997:99 and DUL 976, under yqy).

${ }^{73}$ The unprovenienced reference to "a social term like Arabic hamulah (sic!) 'clan"” in SмIтH 1994:290 is unclear to me. What is probably meant is hamülat- '(a herd) left to graze by itself' (LA 11 849: 'allatī qad 'uhmilat tur' $\bar{a}$ ), a clearly internal Arabic derivation from $\mathrm{hml}$ 'to let alone, to disregard'.

${ }^{74}$ Clearly enough, $h r$ is not the main designation of mountain in Ugaritic and, consequently, not the semantic equivalent of Hbr. har. The basic term for mountain in Ugaritic is $\gamma r$, going back to PCS *tūur- and etymologically and functionally equivalent to Common Aramaic țūra (KogAN 2006a:441, 457-458). The Hebrew reflex of PCS $* \underline{t} \bar{u} r$ - is $s \underline{u} r$, a frequent but clearly non-basic term ('rock, boulder', HALOT 1016). 
a gloss to HUR.SAG in EA 74:20), Pho. hr (DNWSI 293), Hbr. har (HALOT 254).

$\nabla$ The origin of CC *harr- 'mountain' is obscure. ${ }^{75}$

33. hadt 'new moon' (DUL 356).

- Widely attested in cultic contexts.

- Pho. ḥď́ 'new moon; month' (DNWSI 350-351). ${ }^{76}$ Hbr. ḥōdäš id. (HALOT 294).

$\nabla$ CC *hudt- 'new moon, month' (Pardee 2000:151-152) is derived from PS * $h d \underline{t}$ 'to be new'. ${ }^{77}$ As rightly observed by Pardee (2000:158), Ugr. $h d \underline{t}$ has not yet acquired the general meaning 'month' at the expense of PS *warh- 'moon' (> Ugr. yrh DUL 979), so characteristic of Hbr. hōod̈̈s, which does relegate yärạ̣ to a restricted number of passages (cf. BDB 294 and 437 respectively). ${ }^{78}$

34. hln 'window' (DUL 361).

- The most transparent attestation is 1.4 V 61-62 (bl 'ašt 'urbt b bh[tm] hln $b \mathrm{krb} h \mathrm{klm}$ 'I will surely put a skylight in the house, a window in the palace'). In 4.195:15, tmn hilnm 'eight windows' appear among wooden objects.

- Hbr. hallōn 'window' (HALOT 320).

$\boldsymbol{\nabla}$ The origin of CC *hallān- 'window' (Greenfield 1969:98, Ginsberg 1970:103) is uncertain. The Ugaritic form with $h$ makes unlikely the traditional identification with PS *hll 'to bore, to pierce' (BDB 319, cf. HALOT 320).

35. hmt, pl. himyt 'wall' (DUL 364-365).

- Well attested, paralleled by $m g d l$ 'tower' in 1.14 II 21-22 ( ' l l țr mgdl $\mathrm{rkb} \mathrm{tkmm} h \mathrm{mt}$ 'climb on the top of the tower, mount the shoulders of the wall') and $\underline{t} \gamma r$ 'gate' in 1.119:26-27 ( $k$ gr ' $z$ t $\gamma r k m$ krd himytkm 'when a powerful one attacks your gate, a mighty one your walls').

${ }^{75}$ Quite interesting is Tna. hərät 'ridge of mountains, mountain chain, high place, elevation, hill' (TED 16).

${ }^{76}$ Cf. also Krahmalkov 2000:178, who observes that "in Phoenician-Punic, $h d \check{s}$ is never a synonym of $y r h \underline{h}$ "month" - - i. e., the Phoenician usage of $h d \check{s}$ is close to that of Ugr. $h d \underline{t}$ and different from the more advanced Hbr. hōoǚš.

77 A few attestations of the Akkadian adjective ešš 'new' applied to moon (CAD E 376, mostly Nuzi) do not undermine the specifically Canaanite nature of this isogloss.

78 Note the translations 'the new moon of Hiyyaru' (DEL Olmo Lete 2004:530) and 'Neumondphase (des Monats) Hiyaru' (TropPER 2000:385) for ḥdt hyr in 1.78:1. 
- Amarna Canaanite hu!-mi-tu (EA 141:44, a gloss to Akk. dūru), Pho. hmyt (pl.), Moab. ḥmt 'wall, fortress' (DNWSI 381), Hbr. hōmā '(city) wall' (HALOT 298).

$\boldsymbol{\nabla}$ CC *hāmiy-(a)t- 'wall' is probably derived from PS *hmy 'to watch, to protect' (Blau 1957:98, Marrassini 1971:54-56, Ginsberg 1973:134), otherwise represented by JPA hmy 'to see' (DJPA 205), Arb. hmy 'to protect, defend' (Lane 651), Sab. hmy 'to protect' (SD 69), Qat. hmy 'to protect, defend' (LIQ 63), Mhr. hōmi 'to defend' (ML 182), Jib. aḥmí id. (JL 112). The CC term is to be reconstructed as an active participle *hāmiy- $(a) t$ - on the joint evidence of Hbr. hōmā, EA $h u^{!}-m i-t u$ and the syllabic rendering of the Ugaritic lexeme, reliably attested as ha-mi-ti (Huehnergard 1987:125). In view of this remarkable formal peculiarity, Qat. thmy (LIQ 63-64) - even if it really denotes a concrete object ('wall') rather than a more abstract notion ('defensive works') — is no obstacle for regarding *hāmiy-(a)t- as an exclusive CC isogloss. ${ }^{79}$

36. $\boldsymbol{h} r \check{s}$ 'craftsman, manual worker; artisan, builder' (DUL 370).

- Abundantly attested in administrative texts (note especially such compound terms as ḥrš 'anyt 'ship-wright', ḥrš btm 'builder', DUL 371). According to Huehnergard $1987: 50,126$, ha-ra- $\ulcorner\check{s} u$ ? $\urcorner$ in the polyglot vocabulary is probably to be identified with $h r \check{r}$ 'craftsman'.

- Pho. ḥř̌ 'handicraftsman, artisan' (DNWSI 408), Hbr. ḥārāǎs, pl. ḥārāšìm 'craftsman' (HALOT 358).

- CC *ha(r)raš- 'artisan' is likely derived from PS *ḥrš 'to be skillful, intelligent, endowed with magical power': ${ }^{80}$ Akk. eršu 'wise' (CAD E 314, AHw. 246), Ugr. hrrš 'to make spells or incantations', hrrš 'magic spell' (DUL 370-371), Hbr. ḥărāšìm 'magic' (HALOT 358), JPA hāāāš 'sorcerer', ḥäršīn 'sorcery', Syr. heršē 'ars magica' (LSyr. 259), Mnd. hrš 'to enchant, bewitch' (MD 153), Gez. harasa 'to practice sorcery' (CDG 243), Muh. araši, Sod. aräši 'man who has the power of casting the evil eye' (EDG 92).

${ }^{79}$ One is tempted to connect CC *hāmiy-(a)t-with Arb. hāmiyat- 'mass of stones with which a well as cased; all the stones of the casing of a well, matching one another' (LANE 652). If accepted, this comparison - morphologically attractive and implying a kind of semantic "degradation" of an original meaning 'wall' in Arabic — would push *hāmiy-(a)t-back to PCS. Cf. also Yemenite Arabic hāmiyeh 'Hofraum' (BEHnSTEDT 1992:288).

80 Etymological relationship between Akk. eršu, Ugr. ḩřs and Hbr. hāāăš is widely acknowledged (CAD E 314, AHw. 246, HALOT 358, etc.). In HALOT 358 the Hebrew term is

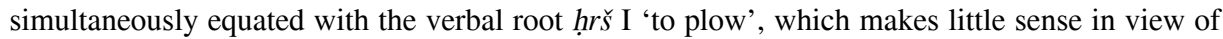
the consistent spelling with $\breve{s}$ rather than $\underline{t}$ in Ugaritic (LOEWENSTAMM 1980:78-80). 
37. hawy Št 'to prostrate onself' (DUL 380).

- Reliably attested in the prostration formula (1.4 IV 25-26, etc.), ${ }^{81}$ together with $h b r$ and $k l$ 'to fall', $k b d$ 'to honour'.

- Hbr. hištaḥ̆awā 'to bow down' (HALOT 296, 1457).

$\checkmark$ The origin of the CC verb for prostrating is disputed (v. Kreuzer 1985:39-41 and Tropper 1990:73-74 for the history of research). According to a widespread opinion (e. g., HALOT 295), these verbs are to be parsed as Št stem forms of the root hwy 'to curl, to coil', unattested in Canaanite but present in Arabic ( $h w y \mathrm{~V}$ 'to assume a round or circular form, to coil, to gather itself together (a snake)', Lane 679). ${ }^{82}$ An alternative derivation from hwy 'to live' has been proposed in Segert 1984:185 ("to ask life for oneself") and Kreuzer 1985:54-60 ("hoch leben lassen; huldigen, anbeten"). ${ }^{83}$ Still another possible etymology is Arb. 'istahya 'to be ashamed, to be shy of somebody' (Lane 680), the semantic relationship between 'to be ashamed' and 'to humiliate oneself' being well conceivable. Independently of its etymological interpretation, this verb represents a highly specific $\mathrm{CC}$ isogloss.

38. $\boldsymbol{k} \boldsymbol{b} \boldsymbol{s}, \boldsymbol{k} \boldsymbol{b} \dot{\boldsymbol{s}}$ 'fuller, launderer' (DUL 429).

- Widely attested in lists of people by professions, but the translation 'fuller' is more etymological than contextual. The same is true of the syllabic form ${ }^{\mathrm{L}} k a_{4}$-bi-s[ú] (Huehnergard 1987:135), although A.MEŠ $k u-u b$-sà-ti-ša 'its water for laundering' (ibid.) is more suggestive.

- Pho. kbs 'fuller' (DNWSI 486, Krahmalkov 2000:223), Hbr. kōbēs ‘fuller', $k b s$ (pi.) 'to full, to clean' (HALOT 459).

$\nabla \mathrm{CC} * k b s$ 'to full, to wash clothes' goes back to PS * $k b s$ 'to tread', represented by Akk. kabāsu 'to step upon; to make compact; to let time pass' (AHw. 415 , CAD K 5), Arb. $k b s$ 'to full up ditches; to complete years by intercalary periods', II 'to squeeze, press together' (WKAS K 28-29), perhaps Soq. kbs 'en-

${ }^{81}$ Further examples see in TROPPER 2000:606-608.

${ }^{82}$ Designations of snake in Aramaic, Arabic and Tigre may be further related (but cf. Kogan 2005:530-531): JPA hiwww̄ (DJPA 197), Syr. ḥewyā (LSyr. 220), Mnd. hiuia (MD 142), Arb. hayyat- (LANE 681), Tgr. ḩway (WTS 90).

${ }^{83}$ This interpretation is accepted as the most likely one in TROPPER 1990:74-75. Tropper rejects EMERTON's (1977) interpretation of hištaḥăwā as hitpa Iēl from šh̆y 'to stoop down' (HALOT 1457), but some of Tropper's arguments apparently miss the point: what Tropper calls hitpalel (presumably for hitpa'lēl) is no " $t \mathrm{~L}$ Stamm" (which is hitpōlēl). Indeed, at least morphologically hištaḥăwā is the expected hitpa qēl (= R-stem) form of šḥy (contra Tropper and PREUSS 1980:249). 
foncer' (LS 213). According to CAD K 7, the meaning 'to full clothes' for Akk. $k a b \bar{a} s u$ is attested in the Sargonic document MAD 1 258:6 (ana TÙG.Š̀̀.GA. DÙ GA-BA-ZI-im 'in order to full a garment', so already Gelb 1957:141), but this highly isolated example, even if correctly interpreted, does not undermine the high specificity of this CC isogloss.

39. $\boldsymbol{k s m}, \boldsymbol{k} \dot{\mathbf{s} m} \boldsymbol{m}$ 'spelt (grain similar to wheat)' (DUL 462).

- Widely attested in economic documents and probably equated with Akk. kunāšu 'spelt' in the polyglot vocabulary. ${ }^{84}$

- Hbr. kussämät 'spelt' (HALOT 490).

$\checkmark \mathrm{CC} *$ kussam-t- 'spelt' may be derived from the PS verbal root $* k s m$ 'to cut, split', represented by Akk. kasāmu 'to cut (down)' (CAD K 240, AHw. 453), Hbr. ksm 'to trim' (HALOT 490), Arb. ksm 'to crumble in one's hand' (LA 12 612), Tna. $k^{w} a \ddot{s} \check{a} m$ 'abbälä 'to dislocate, to break, pulverize' (TED 1621). If this derivation is correct, the CC term would either describe spelt as "grain with split awn" (HALOT 490, Löw apud Hrozný 1913:41) or allude to special techniques of threshing applied to this cereal (Hrozný 1913:41, 56, Fronzaroli 1969:13). ${ }^{85}$ Since CC *kussam-t- is to some extent similar to PS *kunāt- 'spelt, emmer' - Akk. kunāšu (CAD K 536) and Syr. kūnātāa (LSyr. 336) - one wonders whether it might represent a secondary rebuilding of *kunāt- under the influence of $* \mathrm{ksm}$ rather than a completely new independent formation.

40. In 'to sleep, stay the night' (DUL 500).

- Hapax Legomenon in 1.17 I 14-15, the meaning 'to sleep' is reliably deduced from the parallelism with škb 'to lie down' (yd șth yl w yškb [yd] m'izrth $p y \ln$ 'he cast down his cloak, went up, and lay down, [cast down] his girded garment so as to pass the night', Pardee 1997:344).

- Hbr. lyn 'to spend the night, stay overnight' (HALOT 529). It is uncertain whether this root was present in Phoenician: both the reading ytlnn and the meaning 'to spend the night' suggested in DNWSI 575 (and elsewhere) for KAI 24:10 are problematic (Tropper 1993:39-41).

${ }^{84}[k u-n a]-\check{s} u=\ulcorner k u\urcorner-s u ́-m u$ (HUEHNERGARD 1987:139).

${ }^{85}$ This semantic derivation is paralleled by Latin spelta (> French épeautre, English spelt), borrowed from a non-attested early Germanic source eventually going back to PIE * spel- 'to cut, to split' (WH 2 238, 571-572). One wonders, furthermore, whether Sumerian z í z 'spelt' could be borrowed from Akk. $z \bar{z} z u$ with the same meaning, which, in its turn, can be regularly derived from $z \hat{a} z u$ 'to divide, to separate' (contrast AHw. 1534 where Akk. $z \bar{\imath} z u$ 'spelt' is thought to be borrowed from Sum. zíz). 
$\boldsymbol{\nabla}$ As suggested already by Nöldeke (1904:42), CC *lyn 'to sleep, to stay the night' is a denominative verbal root derived from *layl(-liy)- 'night' with dissimilation of sonorants. ${ }^{86}$

41. $\boldsymbol{m s k}$ 'to mix', $m s k(t)$ 'mixture' (DUL 582).

- Widely attested (v. extensively Loretz 1993): 'alp kd ykh b hmr rbt ymsk $b$ mskh 'one thousand jars he takes from the new wine, ten thousands he mixes into his? mixture' (1.3 I 15-17), hm šb'ydty b ș ' hm ks ymsk nhr 'are not seven portions in the bowl, and is not a whole river mixed into the cup?' (1.5 I 20-22), thnm tšky msk 'a second time she serves the mixture' (1.19 IV 61), mskt dlht 'thick mixture' (1.85:3, hippiatric, v. Cohen-Sivan 1983:15).

- Hbr. msk 'to mix', mäsäk 'spiced drink', mimsāk 'jug of mixed wine' (HALOT 605, 595).

$\boldsymbol{\nabla} \mathrm{CC} * m s k$ 'to mix (wine with spices)' is clearly related to *mzg with the same meaning, attested in Syr. mzag (LSyr. 378) and elsewhere in Aramaic. ${ }^{87}$ The ultimate origin of both variants is uncertain. Lipiński (1970:84, cf. also Loretz 1993:248, 254) surmises an Indo-European borrowing (Latin misceo, Greek $\mu$ í $\gamma \omega<$ PIE *meik'-, *meig'-, Buck 1949:335), which is not implausible in view of the conspicuous similarity between the two sets of forms. The reverse direction of borrowing would be improbable because of the semantic narrowness of the Semitic verb.

42. $\boldsymbol{m}$ th 'bed' or 'downwards' (DUL 604).

- Hapax Legomenon in 1.14 I 28-30: tntkn 'udm'th km țklm 'arșh k mhmšt $m$ tth 'his tears drop like shekels to the earth, to the bed like five-shekel weights'. The widely accepted translation '(his) bed' for $m$ tth (Pardee 1997:333, Parker 1997:13, Tropper 2000:691) seems to be superior to 'downwards' (Loretz 1995:112, with references to earlier studies where this interpretation is endorsed). ${ }^{88}$

- For each of the two possible meanings of $m t t h$, reliable Canaanite cognates are found: for the meaning 'downwards' cf. Pho. $m t$ ' what is below'

${ }^{86}$ See further Fronzaroli 1965:150. A similar development but with an opposite direction of dissimilation is behind Akk. niālu 'to lie down' (CAD N 1204 , AHw. 784), v. FronZAROLI 1984:176, HuEHNERGARD 1991a:692, 2002:184.

${ }^{87}$ Arb. $m z \check{3}$ is certainly an Aramaism (JEFFERY 1938:70, 263). The same is true of Hbr. $m \ddot{z} z \ddot{a} g$ in $\mathrm{Ct}$ 7:3 (WAGNER 1966:73-74).

${ }^{88^{\prime}}$ Note in particular that neither Hbr. mátțā nor Pho. $m t$ display the feminine ending - $t$ - found in the Ugaritic form. 
(DNWSI 616) and Hbr. mátțā 'beneath, downwards' (HALOT 573); for the meaning 'bed' cf. Hbr. mitṭā 'couch, bed' (HALOT 573).

$\boldsymbol{\nabla}$ Both CC *matt- 'down' and * $m \mathrm{Vtt}$ t-at- 'bed' are thought to go back to PS *ntw 'to stretch (down)': Hbr. nty 'to spread out, to bow down low, to stretch out' (HALOT 692-693), JPA nty 'to bend over' (DJPA 348), Arb. ntw 'to stretch out (a rope)' (LA 15 387).

43. $n$ 'r 'boy; lad, assistant, serving lad', n'rt 'maidservant' (DUL 616-617).

- Widely attested (but conspicuously absent from epics and myths). For the meaning 'boy, lad' note, in particular, the use of $n$ ' $r$ together with 'att 'wife' in 2.33:28-29 and in parallelism with $s \gamma r$ 'boy' in 1.107:8-9.

- Eg.-syll. na״ 'a»ru „na 'soldiers' (Hoch 1994:182-183), ${ }^{89}$ Pho. and Amm. n'r 'young boy' (DNWSI 739), Hbr. na 'ar 'lad, adolescent', na ‘̆rā 'young unmarried girl' (HALOT 707).

$\boldsymbol{\nabla}$ The origin of $\mathrm{CC} * n a$ ' $r$ - 'boy, lad' is obscure. None of the two widely attested homonymous verbal roots ${ }^{*} n$ ' $r$ ('to cry, shout' ${ }^{90}$ and 'to stir, raise' ${ }^{91}$ ) provide a suitable source of derivation. Arb. nu'arat- 'foetus in the womb of female wild ass' (LA 5 260) is semantically more attractive, but too isolated to be taken as a reliable cognate. Hoch (1994:182-183) tentatively connects *na' $r$ with Akk. niru 'a word for troops' (CAD N $\mathrm{N}_{2}$ 265), emphasizing the military connotations of the $\mathrm{CC}$ term. ${ }^{92}$

${ }^{89}$ As Hoch correctly observes, in view of the complete absence of this root from Aramaic, one is compelled to assume that the Egyptian rendering reflects a Canaanite language with nunation in the plural (such as Moabite).

90 Akk. na'āru 'to roar' (CAD N 1 7, AHw. 694), nā'iru 'raging, roaring' (CAD N 150 , AHw. 709), Syr. nə'ar 'clamavit (asinus)' (LSyr. 435), Arb. n'r 'to utter a noise' (LANE 2815), Amh. anarä 'to cause to resound' (AED 1018). Note that according to KopF 1976:155 "könnte $n$ ' $r$, das ja auch von einem Kleinkind gebraucht wird ... ursprünglich soviel wie Schreihals bedeuten”.

91 JPA $n$ ' $r$ 'to shake out' (DJPA 354), Tgr. na'r 'mischief, quarrel, revolt' (WTS 335), Tna. täna 'rärä 'to be prideful' (TED 1351), Amh. narä 'to bounce upward, rise up' (AED 1018).

92 The Akkadian word, attested several times in lexical lists of the first millennium, is not separated from nēr '600' in AHw. 779. Cf., alternatively, Akk. nāru as an element of personal names in OA and OB (na-ar-bi-tim, na-ar-É.A, ku-bi-na-ri, CAD N 1376 ) and translated as 'eine Personenbezeichnung' in AHw. 749. Could it be tentatively interpreted as a (WS?) lexeme meaning 'servant, lad'? In FARBER 1989:54-56 a hitherto unrecognized Akkadian lexeme na'ru 'child' has been identified in the colophon of a $1^{\text {st }}$ millennium Baby-Beschwörung. Farber furthermore refers to Rотн 1987:739-746 where nāru and närtu in NB documents, traditionally understood as 'male/ female singer', are reinterpreted as WS borrowings denoting lad and lass respectively. For a possible precedent in OB Mari see finally Kogan 2011. 
44. $\boldsymbol{n} \boldsymbol{b} \boldsymbol{k}, \boldsymbol{n p \boldsymbol { k }}$ 'fountain, spring', $m b \boldsymbol{k}$ 'source, spring' (DUL 617, 523).

- Reliably attested in 1.14 V 1-2 (nbk 'fountain' $\| m k r$ 'spring') and 1.4 IV 21-22 (mbk nhrm 'source of the two rivers' || 'apk thmtm 'streams of the two deeps'). Numerous syllabic attestations of nabku and nab(a)kūma are discussed in Huehnergard 1987:151.

- Hbr. nibkē yām 'sources of the sea' (Job 38:16), mibbəkī nəhārōt 'source of the rivers' (Job 28:11), nbwky mym (1Q Hod 3:15).

$\nabla$ As suggested in HALOT 663, CC *nabk- 'spring, stream' is derived from PCS * $n b g$ 'to spring up' with word-final devoicing $* g>k$ : JBA $n b g$ 'to break forth' (DJBA 725), Syr. nbag 'scaturivit, prorupit' (LSyr. 410), Mnd. nbg 'to (a)rise, spring up' (MD 287), Arb. $n b \check{z}$ 'to go out (a partridge from its den)' (TA 6 229).

45. $\boldsymbol{n b t}$ 'honey' (DUL 618).

- Widely attested, paralleled by yn 'wine' (1.14 IV 1-2) and šmn 'oil' (1.6 III 6-7).

714).

Pho. npt 'honey’ (Tomback 1978:219), ${ }^{93}$ Hbr. nōpät id. (HALOT 713-

$\nabla$ CC *nub-t- 'honey' goes back to PS *nūb(-at)- 'bee' (SED II No. 156), represented by Akk. nūbtu (CAD N 2309 , AHw. 800), Arb. nūb- (Lane 2863), Gez. nahb (CDG 393), Jib. nibbót (JL 198). The Ugaritic form strongly supports this derivation, as it preserves the original $* b$, devoiced before $t$ in Hebrew and Phoenician $\left(* n u b-t->*^{*} n u p-t-\right)$. The status of $* n u b-t$ - in Hebrew in Ugaritic is not identical: in Ugaritic, PS *dibš- 'honey' left no trace (a nearly unique case throughout Semitic), whereas Hbr. dabaš is clearly the main term for honey, of which nōpät is a rare poetic synonym.

46. $\boldsymbol{n g h}$ 'to butt each other' (DUL 622).

- Hapax Legomenon in 1.6 VI 17-18 (ynghnn $k$ r'umm 'they butt each other like wild bulls').

- Hbr. ngh 'to gore' (HALOT 667).

$\boldsymbol{\nabla}$ The origin of CC *ngh is uncertain. If Amh. tänagga 'to collide, bump into one another' (AED 1059), Muh. Msq. Gog. Sod. (tä)nagga, Wol. tänagä 'clash (cattle, objects), collide' (EDG 453) are related (so tentatively Leslau

${ }^{93}$ Hapax Legomenon in KAI 78B 8, not very reliable (cf. DNWSI 749, KrahmaLKov 2000:333, Томваск 1978:219). 
1956:33), the meaning 'to butt, to gore' in CC could represent a semantic development from 'to collide, clash', although the reverse is also possible. One wonders whether Arb. nžh 'to succeed, to attain one's wish' (Lane 2766) could be related with an original meaning 'to butt', 'to fight'.

The root $n g h$ with the meaning 'to gore' is relatively widespread in Jewish Aramaic (both JPA and JBA, v. DJPA 340 and DJBA 729 respectively), but its total absence elsewhere in Aramaic makes one suspect that the attestations in the Jewish dialects are due to Hebrew influence.

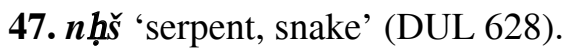

- Reliably attested, notably in 1.100 (paralleled by bn bthn 'sons of the snake' in 11. 73-74).

- Hbr. nāḥ̄ăs 'snake' (HALOT 690).

$\nabla$ As argued in SED II No. 159, CC *naḥaš- 'snake' likely goes back to PS *naḥaš- with a more general meaning 'wild animal', otherwise represented by Akk. $n \bar{s} \check{s} u$ 'lion'(CAD N 2 193, AHw. 783). ${ }^{94}$ Attestations of Ugr. $n h ̣ \breve{s}$ are much less numerous than those of $b \underline{t} n$ (DUL 252), and it was probably the latter term that functioned as the main designation of snake in Ugaritic. Conversely, in Hebrew, $n \bar{a} h \grave{a} \bar{s} \breve{s}$ clearly enjoyed the basic status.

48. $\boldsymbol{n t} \underline{\boldsymbol{k}}$ 'missiles (projectile, dart)' (DUL 654).

- Reliably attested in 4.169:3 (list of weapons, together with kšst 'bow'

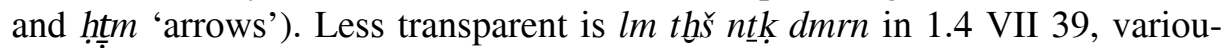
sly translated as "why do you shake with fear, you who take up arms against Dimārānu' (Pardee 1997:263) and 'why do you fear the darts? of the "Powerful One?", (DUL 654).

- Hbr. näšäḳ (nēšäkn) 'equipment, weapons; order of battle, battle' (HALOT 731).

$\nabla$ Hbr. näs̆äk is usually compared with Arb. nsq 'to put in order' (LA 10 424), Gez. nasaka 'to arrange in order, join closely' (CDG 403), which implies a semantic derivation from 'order of battle' to 'war, warfare, weapons' (Kopf

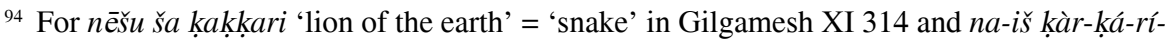
$i m=$ Sum. n i n.k i in EV 0049 v. GeORGe 2003:896-897 and SJÖBERG 1996:20-21 respectively. PS *naḥaš- 'animal', in its turn, may well go back to the verbal root *nḥš 'to live, to be alive' preserved in Akk. nêšu (clearly < *nḥš as shown by the Sargonic spelling na-'à-ǎs, HasSELBACH 2005:280). The semantic development is more than usual, cf. BUCK 1949:137 for numerous IE precedents and, in the Semitic domain, Hbr. hayya (HALOT 310). 
1976:206-208). This comparison is, however, phonologically problematic: on the one hand, reliable examples of PS $* \check{s}>$ Ugr. $\underline{t}$ are few; $;{ }^{95}$ on the other hand, CDG 403 plausibly relates Arb. $n s q$ and Gez. nasaḳa to Akk. šutassuḳu 'to put in order, to make ready, to prepare' (CAD N 222 , AHw. 753). ${ }^{96}$ If this comparison is correct, it is $*_{s}$ rather than $*_{\breve{s}}$ that has to be postulated in the proto-form, which is definitely incompatible with either Ugr. $t$ or Hbr. $\breve{s}$. According to DUL 654, Ugr. $n t \underline{k}$ is probably "an allomorph and secondary lexicalization of $n s k$ ", which does not look convincing. ${ }^{97}$

49. p'amt (pl.) 'time' (DUL 659).

- Well attested, the meaning 'time' (vicis) is clear in such examples as 1.43:6-8: țl ș șin šlmm šb' p'amt l'ilm 'three heads of small cattle as a wellbeing offering, seven times, for the gods' (Pardee 2000:214-215, 236).

- Pho. p'm (DNWSI 929), Hbr. pa 'am ‘time' (HALOT 952).

จ CC *pa'm- (pl. *pa 'am-āt-) 'time' undoubtedly represents a semantic extension of PS *pa 'm- 'foot' (SED I No. 207), although its phonetic split into $p$ ' $n$ 'foot' and $p$ 'amt 'times' in Ugaritic remains enigmatic (cf. Tropper 2003:666-670). ${ }^{98}$

50. $\boldsymbol{p k}$ ' 'to obtain, to acquire' (DUL 677, 974). ${ }^{99}$

- Well attested, the most reliable examples include 1.14 I 12-13 ('att șdk l ypk mtrht yšrh 'he did not obtain his lawful wife, no legitimate spouse'), 1.4

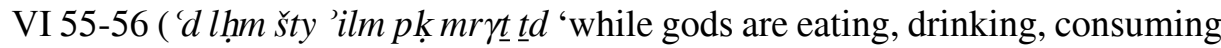
sucklings'), 1.103+:13 (mlkn l ypk šs $p$ ] ’ 'the king will not obtain progeny'), 1.4

${ }^{95}$ For a recent collection of potentially relevant cases v. TROPPER 2000:109-111. Tropper's generally positive attitude towards these examples is, in my opinion, rarely justified (contrast BLAU's skepticism in 1977:73-78).

${ }^{96}$ To be sure, Akk. nasāḳu 'to select' (AHw. 753, CAD N 2 21) may also be related, with a plausible meaning shift.

${ }^{97}$ For a more detailed exposition of this hypothesis v. SANMARTín 1989:344-345, whose evaluation of the possible relationship between Ugr. nțk and Hbr. näs̆äk is, in my opinion, hypercritical.

${ }_{98}$ According to Tropper, the unexpected ' in p'amt is due to foreign (more concretely, Phoenician) origin of the Ugaritic word. This hypothesis is hardly provable given the fact that the actually attested Phoenician forms are always spelled with '.

${ }^{99}$ DUL splits the available attestations into two variant roots $p(w) k$ and $y p k$, but there is hardly any compelling reason to postulate $y p k$ in any of the pertinent passages (for $y p k$ as a short form of the prefix conjugation from $p(w) k$ in 1.14 I 12-13 v. TROPPER 2000:700). 
VI 47 (špk 'ilm krm yn 'he provides the gods with rams and wine' ${ }^{100}$ and passim in the following lines of this text).

- Pho. pwk 'to find, to obtain, to encounter' (DNWSI 903), ${ }^{101} \mathrm{Hbr} . p w k$ (hip.) 'to reach, to obtain, to find; to offer' (HALOT 920). Amarna Canaanite ia-pa-ak-ti (EA 64:23) almost certainly belongs to this root, although the commonly accepted meaning 'I sent' (Moran 1992:135) is somewhat unexpected for the basic stem.

$\boldsymbol{\nabla} \mathrm{CC} * y p k / * p w k$ 'to obtain, to acquire', causative 'to provide' (Greenfield 1969:99) is usually compared to Common Aramaic *npk 'to go out' and related terms elsewhere in Semitic (v. extensively Kogan 2005:524). Semantically more suitable can be, however, Arb. $w f q$ 'to be right, agreeable with what was wished', II 'to accommodate, to adapt, to dispose' (Lane 3057), which would imply an original basic meaning 'to fit, to be suitable, to be available'.

51. pnt 'joint, vertebra' (DUL 676).

- Attested in the descriptions of the buckling bodies of the gods $\mathrm{Ym}(\mathrm{l}$

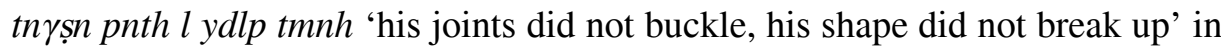
1.2 IV 17-18) and ' $n t$ ( $t \gamma \underline{s}$ pnt kslh 'anš $d t \underline{t}$ trh 'the joints of her loins contracted, the muscles of her back' in 1.3 III 34-35). Anatomic connotations of pnt in these passages are not in doubt, ${ }^{102}$ but there are reasons to suspect a metaphoric application of an originally architectural term ('corner' or the like, cf. 'corners of the back' in de Moor 1971:137). Such a possibility is supported by the meaning of the Hebrew cognate (v. below) as well as by the parallelism with tmn in 1.2 IV 17-18, since the latter lexeme is most probably borrowed from (or at least identical to) Akk. temmennu 'foundation' (CAD T 337). ${ }^{103}$ Note, finally, that the Hebrew cognate of Ugr. $d l p$ is used about a house in Qoh 10:18 (de Moor 1971:137, 1980:426).

- Hbr. pinnā 'corner, corner-stone' (HALOT 945).

$\boldsymbol{\nabla}$ The origin of CC *pinn-at- 'joint, corner' is uncertain. The evidence

${ }^{100}$ Possible interpretations of the difficult syntactic arrangement of this passage are extensively treated in PARDEE 1997:262.

101 The relevant Phoenician forms are commonly interpreted as belonging to the causative stem (FRIEDRICH-RöLLIG 1999:108).

102 A more specific connection with joints, articulations is supported by the parallelism with 'anš which, at least on etymological grounds, should be interpreted as ‘(sciatic) tendon' (SED I No. 201).

103 The parallelism 'corner' || 'foundations' is attested in the Old Testament: pinnā $\|$ mōsādōt (Jr 51:26, cf. also Is 28:16). 
for a PS verbal root *pnn 'to bend, crook' from which such a lexeme could be potentially derived ${ }^{104}$ is insufficient. ${ }^{105}$

CC *pinn-at- 'corner' has no reliable Aramaic cognate: Syr. pānyā 'angulus' (LSyr. 578) does render Hbr. pinnā in Neh 3:31-32, but it clearly belongs to a different consonantal root (pny) and should be considered an occasional and probably artificial phonetic approximation to the Hebrew original. ${ }^{106}$ JPA pynh 'cornerstone' must be a Hebraism (with DJPA 431).

52. $p \check{s}^{\text {c ‘ }}$ rebellion, transgression' (DUL 686).

- Hapax Legomenon in 1.17 VI 43-44: l 'akrryk b ntb pš' ... b ntb g'an 'I will certainly meet you on the path of transgression ... on the path of pride'.

- Hbr. päša' 'crime' (HALOT 981).

$\boldsymbol{\nabla}$ There is no reliable etymology for CC *paš - 'crime, transgression'. Syr. pša' 'topruit, perterritus est; insipienter egit', pašš $\bar{\imath}$ ' $\bar{a}$ 'tepidus' (LSyr. 613) are semantically rather remote. The wide presence of $p \check{s}^{c}$ 'to be negligent, to harm, to transgress' in JBA (DJBA 944) is probably due to Hebrew influence. One wonders whether Akk. pī̌stu 'insult' (CAD P 433), 'Beschimpfung, Beleidigung' (AHw. 869) may be related to *paš - rather than derived from the somewhat ephemeral *wapāšu (AHw. 1459).

53. ptt 'linen, linen fabric' (DUL 688).

- Widely attested in economic documents (Sanmartín 1979:727).

- Pho. pšt 107 ‘flax’ (DNWSI 947), Hbr. päšät ‘flax, linen’ (HALOT 983).

$\nabla$ The origin of $\mathrm{CC} * p \mathrm{~V} \underline{t}-t$ 'flax' is obscure. ${ }^{108}$

104 Cf. Buck 1949:900: “words for 'corner' are connected with roots for 'bend' or with words which ... suggest the notion of a sharp bend or angle, as those for 'knee', 'elbow', 'wedge', 'hook'”.

105 According to DUL 676, the verb pnn 'to distort, change' is in fact attested in Ugaritic, but the only putative example (tpnn ' $n$ bty ' $n$ btt tpnn tpnn in 1.96:5-6) is more than problematic (cf. DEL Olmo LeTE 2004:381-382). Arb. fnn 'to drive away; to cheat' (LANE 2446), adduced as cognate in DUL 676, is semantically rather remote. Cf. perhaps Cha. Enm. Gyt. fwänä, Eža End. Muh. $f^{w} \ddot{a n n} \ddot{a}$ 'opposite side, reverse side, curved, bent, crooked, not straight' (EDG 232), borrowed from Cushitic according to Leslau.

106 The normal meaning of the Syriac word is 'the turn of the day, declining day, early evening' (PS 3171). The same is true of its cognate in JBA (DJBA 915).

107 For the possible Greek rendering $(\zeta \varepsilon \rho \alpha) \varphi \sigma 1 \sigma \tau$ (with variants) v. Löw 1881:406, 411.

${ }^{108}$ It is not clear to me what is meant by "numerosi paralleli nelle altre lingue semitiche" in RIBICHINI-XELLA 1985:17. 
54. $\boldsymbol{r b d}$ 'to prepare, get (a bed) ready', $m r b d$ 'bedspread, counterpane' (DUL $731,573)$.

- The specific connection with bed, couch is obvious for both the verb (trbd 'řs pdry 'the bed of Pdry is prepared' in 1.132:2-3) and the noun (mrbd $m s ̌ k b t$ 'a bedspread' in 4.385:9).

- Hbr. rbd 'to prepare a couch', marbaddim (pl.) 'cover' (HALOT 1176, 631). ${ }^{109}$ Amarna Canaanite ma-ar- $\left.r b a\right\urcorner-d[u]$ (EA 120:21) is translated as 'carpet' in Rainey 1978:81, but the exact meaning of this form, found in a list of goods in a partly broken context, is hard to establish (cf. 'blanket' in Moran 1992:199).

$\boldsymbol{\nabla} \mathrm{CC} * r b d$ 'to prepare, cover a bed' likely derives from PCS * rbd with a more general meaning 'to cover, to put in layers': Pho. rbd 'to pave' (DNWSI 1052), Hbr. pB. räbäd 'mosaic pavement' (Ja. 1455), Arb. rabìd- 'dates laid one upon another in an earthen pot' (Lane 1010).

55. $r$ tt 'net' (DUL 750).

- Hapax Legomenon in 1.4 II 31-32, the meaning 'net' is supported by the context: $d g y$ rbt 'ațr $[t y m] k \underline{h} r \underline{t} t b d k$ 'o fisherman of the great lady 'atrt $y m$, take the net in your hand'.

- Hbr. räs̆ät 'net' (HALOT 1298).

$\nabla$ The etymology of $\mathrm{CC} * r \mathrm{~V} \underline{t}-t$ - 'net' is uncertain, derivation from PS * wrt 'to inherit, to possess', tentatively accepted in both HALOT and DUL, is semantically weak.

56. $\boldsymbol{s} \boldsymbol{b} \boldsymbol{b}$ 'to turn (round)' (DUL 752)

- Reliably attested: $s b$ ksp l rkm hrs nsb l lbnt 'silver turned into sheets?, gold turned into bricks' (1.4 VI 34-35), ...dn'il ysb p'alth bṣkl yph b y $\mathrm{\gamma lm}$ '... $D n^{\prime} i l$ went around his waste land? and distinguished a green shoot in the untilled land"' (1.19 II 12-13), tr 'arș w šmm sb l kșm 'arș 'go through the earth and the heavens, turn to the end of the earth' (1.16 III 2-3).

- Pho. $s b$ 'to turn over', $s b b$ 'round about', Amm. $s b b t$ 'surrounding' (DNWSI 772), Hbr. $s b b$ 'to turn oneself around' (HALOT 738).

$\nabla \mathrm{CC} * s b b$ 'to turn' may be related to Arb. sibb- 'turban', sabab- 'cord, rope', sabīb- 'a lock of hair' (Lane 1285-1286), ${ }^{110}$ Tgr. šäbašäbä 'to put in folds

109 The noun is directly connected with bed in Pr 7:16 (mar $\underline{b} a d d \bar{i} m$ rābadtī 'ar̂sī 'I have decked my bed with covers').

${ }^{110}$ One wonders whether Arb. tasabbaba 'to traffic' (Lane 1284) could go back to an original meaning 'to turn around', which would offer an excellent parallel to Akk. sāhiru 'peddler' (CAD S 60-61), Hbr. sōḥēr 'trader, dealer' (HALOT 750), cf. LANDSBERGER 1967:176-190. 
(garment)' (WTS 216), Tna. säbsäbä 'to tuck up, to roll up' (TED 704), Amh. šäbäššäbä 'to wrinkle, to pleat' (AED 636), although Akk. šibbu 'belt, girdle' compared in CDG 483 makes this identification problematic (Akk. $\check{s}$ does not regularly correspond to Hbr. $s$ ). Sab. $s_{3} b b$ 'to surround an enemy' (Biella 501) would provide a more direct cognate, but the meaning of this military term $(\mathrm{Ha}$ pax Legomenon in Ja 631:32-34) is quite uncertain (cf. 'to engage (with enemy) at close quarters' in SD 397). ${ }^{111}$ Whether Gez. 'asbāb 'guards, sentinels' goes back to this root is, contra CDG 483 and LLA 359, completely uncertain. ${ }^{112}$

The verb $s b b$ is attested twice in an Old Aramaic inscription from Sefire ( $y^{\prime}$ th hld mlkn wysbn<y> 'if one of the kings comes and surrounds me, KAI 222B 28, $k l$ zy ysb 'whoever lives around", ibid. 34), which prompts one to treat it among common Semitic lexemes still present in Old Aramaic inscriptions, but lost or marginalized in later Aramaic (Kogan 2005:557-559). Its nearly complete absence from Official and Middle Aramaic ${ }^{113}$ might suggest that already in Old Aramaic $s b b$ was not the basic verb with the meaning 'to turn' (in contrast to Hebrew and Ugaritic, where the basic status of $s b b$ is not in doubt), presumably being replaced by $* s h r\left(\mathrm{cf}\right.$. HALOT $\left.739^{114}\right)$. This assumption cannot be proved, since the concept 'to turn' does not seem to be attested anywhere else in the Old Aramaic corpus.

57. $s p r$ 'to count, number; to recite' (DUL 766), spr 'number, inventory' (ibid. 769), $m s p r$ 'recitation, story, talk' (ibid. 583).

- The meaning '(to) count' is reliably attested in 1.17 VI 28-29 ('ašsprk ' $m$ bl šnt ' $m$ bn 'il tspr yrhm 'I will let you count the years with $B$ 'l, with the son of 'il you will count the months') and 1.14 II 37-38 (bpt d bl spr thnn d bl hg 'the irregular troops without number, the archers without count'). The meaning 'to recite' is restricted to the prescriptions for cultic recitation (notably in colo-

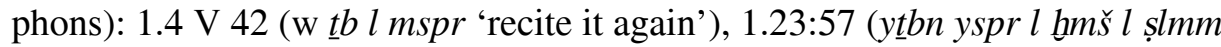
'he will recite it again five times in front of the statues'), etc.

- Pho. mspr 'number' (DNWSI 666), Hbr. spr (pi.) 'to count; to report, to tell', mispār 'number' (HALOT 766, 607).

111 Jamme's own translation 'they turned aside' clearly depends on the Hebrew and Ugaritic etymology (JAMME 1962:134).

${ }^{112}$ Gez. sabba, sababa 'to go around, circle', adduced in CDG 483 from a recent work of native lexicography, is not attested in the sources and seems to be an artificial creation with no relevance for the etymology of Hbr. $s b b$.

113 The only possible exception is Mnd. sub 'to surround' (MD 320), very poorly attested.

114 The precise meaning of the statement "Arm. made more emphatic by $s h r$ " escapes me. 
$\nabla$ CC *spr 'to count' is likely related to Gez. safara 'to measure' (CDG 488) and its cognates throughout ES (note especially Amh. säffärä 'to measure, to count', AED 595). ${ }^{115}$ It is tempting to compare also Sab. $s_{1}$ frt 'extent, measure, length' (SD 125, Biella 342) ${ }^{116}$, but Sab. $s_{1}$ does not regularly correspond to Hbr. $s$. No comparable forms are attested in the rest of WS, notably in Aramaic. ${ }^{117}$ Contra HALOT 765-766, CC *spr 'to count; to tell' is to be strictly separated from the widely attested lexemes with the prototypes *sipr- 'writing, inscription, document' and *sāpir- 'scribe', which are not genuinely West Semititc, but ultimately go back to Akk. šipru and šâpiru.

\section{8. șmḳ 'raisin' (DUL 786)}

- Hapax Legomenon in 4.14:17 ([l]tḥ dblt lth șmḳm 'one ltḥ of dry figs, one lth of raisins') as well as in the combination dblt ytht $w$ șm $\mathbf{k} m$ y $\underline{t} n m$ in hippiatric texts (for which see No. 78 in the present section).

- Pho. șmḳ 'dried fruit, rasin’ (DNWSI 970, Krahmalkov 2000:418), Hbr. șimmūḳim 'cake of dried grapes' (HALOT 1033).

$\nabla \mathrm{CC} * s \mathrm{VmVk-}$ 'raisin' goes back to PS * $\operatorname{smk}$ 'to press, to squeeze; to dry, to shrivel up': Hbr. șmk ‘ to dry up, wither' (HALOT 1034), JPA șmk 'to shrink, to dry out' (DJPA 466), JBA șmk 'to be dry' (DJBA 967), Mnd. șamḳa 'shriveling' (DM 387), Tgr. çämkäa 'to pinch, to touch' (WTS 623), Tna. șämäḳ ${ }^{w} \ddot{a}$ 'to wring, to squeeze, to extract' (TED 2556), Amh. ç̣̈mmäkä 'to wring, to squeeze, to compress' (AED 2206), Har. çämäkä 'to squeeze, wring' (EDH 51), Zwy. țämäkäa, Sel. Wol. aṭämäkä, Sod. çämmäkä, Eža ç̧mammäkäa 'to wring wet clothes, to squeeze water out of clothes or dough' (EDG 621), perhaps Arb. șāmiq- 'hungry and thirsty' (LA 10 248). JPA șimmūḳin 'raisins' (DJPA 463) is almost certainly a Hebraism. The similarity between ${ }^{*} \mathbf{s} \mathrm{VmVk}$ - and Akk. muzīku 'raisin' (CAD M $2322, \mathrm{AHw} .692$ ) observed in DUL 786 is conspicuous, but probably accidental.

59. $\check{\boldsymbol{s}} \boldsymbol{d}$ 'open field, stretch of cultivated land; field, land, plot, estate, farm' (DUL 807).

- The meaning 'plot of cultivated land', crucial for the exclusively Canaanite status of this term, is abundantly attested, especially in economic and administrative texts.

${ }^{115}$ For the semantic shift cf. Lat. computare $>$ Fr. conter as well as proto-Germanic *tala 'Berechnung, Zahl; Rede' (FICK 1909:112).

116 Hapax Legomenon in C 570:5-6: wlkd bn $s_{1}$ frt nhln nḳbn yṣ̂s’n tḥrw byn nhlnhn $n k \underline{k}[b] n$ $w n$ ' $w n$ 'und es sollen von Ausmaß der Palmenplantage Nqbn hinausführen Bewässerungsanlagen? zwischen den beiden Palmenplantagen Nqbn und N 'wn' (translation from Sima 2000:218-219).

117 JBA spr 'to count' (DJBA 827) is certainly a Hebraism. Sporadic attestations of Syr. spar 'narravit; garrivit' in LSyr. 493 are due to Hebrew influence as well (cf. PS Supplement 239). 
- Amarna Canaanite ŠA-TE-e (EA 287:56), ${ }^{118}$ Pho. $\check{s} d$ 'field, plain' (DNWSI 1110), ${ }^{119} \mathrm{Hbr} . \hat{s} a \bar{a} d \ddot{a}$ 'pasture, open fields; field, arable land' (HALOT 1307).

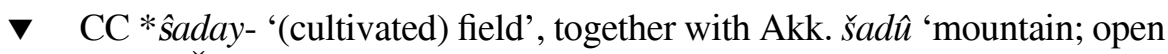
country' (CAD Š 4 49, AHw. 1124), yields PS * ŝadaw- ${ }^{120}$ 'open country, wild, uncultivated place' (Fronzaroli 1968:269-270, 287). ${ }^{121}$ It is usually assumed that this PS term is not reflected in Aramaic (Blau 1977:101), but note Mnd. sadia 'field, open space, plain, desert' (DM 310). ${ }^{122}$ Sab. $s_{2} d w$, often compared to Hbr. ŝāda and Akk. šad $\hat{u}$, is an obscure word tentatively rendered as "mountain", "cultivated land" in SD 131 and 'hillside, terraced hillside' in Biella 511. ${ }^{123} \mathrm{Cf}$. perhaps Amh. säd (d)a 'place having no fence, hedge or wall' (AED 574). The meaning 'cultivated field' for *sadaw- is a highly specific CC innovation (Fronzaroli 1969:9) with no precedent in other Semitic languages, where this concept is expressed, inter alia, by the reflexes of PS * hakl- (Fronzaroli 1969:8-9, 26): Akk. eklu (CAD E 249, AHw. 231), Syr. ḥaḳlā (LSyr. 252), Arb. haql- (Lane 612). Remarkably, PS * hakl $\mathrm{l}$ - is not attested (presumably, lost) in Canaanite.

60. šmb 'to be glad, rejoice', šmhtt 'joy' (DUL 825).

- Widely attested, paralleled by $g l$ 'to rejoice' and șhk 'laughter' in 1.16 I 14-15 and 1.3 II 25-26 respectively.

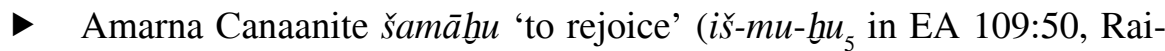
ney 1978:92), ${ }^{124}$ Amm. šm $h$ 'to be glad' (DNWSI 1160), Hbr. smḥ 'to rejoice', simḥā ‘joy’ (HALOT 1333).

118 A gloss to Akk. ugāru. The contextual meaning is admittedly 'countryside' rather than 'cultivated field'.

119 The meaning 'cultivated field' is clear in $\check{s} d$ ' $m$ krm 'field or vineyard' (KAI 287:6).

120 The PS reconstruction with $*_{-} w$ (rather than $-y$ ) seems to be assured by well-attested spellings with -u-l-w-in Sargonic (śa-dú-e, śa-dú-im) and Old Assyrian ( $\check{s} a-a d-w i-i m, \check{s} a-d u-i m)$, v. KIENAST 1994:278-280 and CAD Šs 51 respectively.

${ }^{121}$ For the semantic relationship between 'mountain' and 'countryside' in Semitic v. CDG 121, in connection with Gez. dabr 'mountain' vs. Hbr. midbār 'desert, steppe'.

${ }^{122}$ This Mandaic lexeme is so much isolated in Aramaic that one is tempted to surmise a Canaanite borrowing (for such a possibility cf. D. Boyarin's remarks on Mnd. șhk 'to laugh' apud STEINER 1977:118).

${ }^{123}$ These translations have been recently challenged in SIMA 2000:309 in connection with CIH 660:4 and Robin-Kāniț 5:2: "Beides passt im Kontext überhaupt nicht ... šdw ein Bauwerk, ein Haus, einen Teil eines Hauses o. ä. bezeichnet” (v. already RoBIN 1982:52).

124 This interpretation is not universally accepted, cf. MORAN 1992:184, RAINEY 1996 III 185-186. 
$\boldsymbol{\nabla}$ The origin of CC * $\hat{s} m h$ 'to rejoice' (Greenfield 1959:151) is unclear, although one cannot exclude (with Greenfield and Kopf 1976:190) an eventual relationship to PS * Ŝmh 'to be high, tall', represented by Akk. šamāhu 'to grow

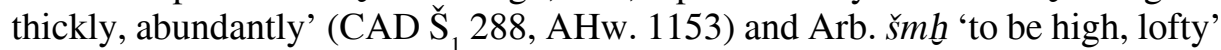
(Lane 1595). ${ }^{125}$ Soq. šámhal 'long' belongs to the same root according to LS 418 ("un augmentatif à suffixe $l$ de l'ar. šmb̆"), but this is unlikely in view of the irregular sibilant correspondence.

\section{1. šns 'to gird oneself' (DUL 833)}

- Hapax Legomenon in 1.3 II 11-13: 'tkt r'išt l bmth šnst kpt b ḥbšh 'she attached heads to her back, bound hands to her gird'.

- Hbr. šns 'to gird' (HALOT 1607). ${ }^{126}$

$\nabla \mathrm{CC} * \check{s} n s$ 'to gird' has no reliable etymology. Comparison with Arb. $\check{s} n \underline{\text { ' }}$ 'to be attached to something' (LA 7 55) suggested in Yahuda 1903:711 is semantically attractive, but implies two phonological irregularities. ${ }^{127}$

62. ̌̌ph 'family, offspring, descendants, clan' (DUL 835).

- The meaning 'son, descendant' is clear in 1.14 III 48-49 (wld šph l krt w $\mathrm{\gamma lm}$ $l$ 'bd 'il 'to bear a descendant to Krt, a boy to 'il's servant') and 1.16 I 9-11 (krt bnm 'il šph ltpn $w$ kdš ' $K r t$ is a son of ' $i l$, a descendant of the Benevolent and the Holy One'). The collective interpretation ('family') is likely in b klhn šph y'itbd 'the family perished in its entirety' (1.14 I 24, note a few other collective designations of family in this episode), but the presence of $y r \underline{t}$ 'heir' in the parallel line 25 suggests that the meaning 'descendant, offspring' is prominent also in this passage.

- Pho. šph 'clan, family' (DNWSI 1181), Hbr. mišpāḥ̄a 'extended family' (HALOT 651). ${ }^{128}$

$\boldsymbol{\nabla}$ The origin of $\mathrm{CC} * \check{s} \mathrm{~V} p h$ - 'family' is uncertain as none of the extant $* \check{s} p h$ roots elsewhere in Semitic allows for a transparent semantic development into 'family, progeny'. ${ }^{129}$

125 Note especially the derived meanings 'to thrive, to flourish, to attain extraordinary beauty or stature' in Akkadian and 'to be proud' in Arabic.

126 Hapax Legomenon in 1K 18:46: wa-yšannēs motnāw 'he girded his loins'.

127 For -ṣ note however JPA šnș 'strap, lace' (DJPA 560), JBA šnṣ 'to tighten a cord', šnāṣā 'lace' (DJBA 1166).

${ }^{128}$ It is hard to say whether Hbr. šipḥa 'slave-girl' is etymologically related to mišpāhāa (cf. HALOT 1620, REUTER 2006:406).

129 HALOT 1620 mentions Arb. sfh 'to pour, to shed' (Lane 1369), with no comments on the hypothetic semantic derivation. BDB 1046 tentatively compares Arb. $s f h$ III 'to commit 
63. ̌̌t 'to place, set, set up' (DUL 848).

- Passim in the Ugaritic corpus.

- Pho. $\check{s} t$ 'to place, to put, to establish' (DNWSI 1130), Hbr. ̌̌yt 'to set, stand, place' (HALOT 1483).

$\nabla \mathrm{CC} * \check{s} y t$ 'to place, to put' is to be identified with Akk. šêtu 'to remain, to be left over; to leave' (CAD Š 341 , AHw. 1221). Since the semantic shift 'to leave' > 'to put, place' is relatively well attested, ${ }^{130}$ there are good reasons to attribute the meaning 'to leave' to PS $* \check{s} y t$ and to consider the meaning 'to put' as a CC semantic innovation. ${ }^{131}$

Ugr. $\check{s} t$ and Hbr. $\check{s} y t$ do not match exactly from the functional point of view. While Ugr. $\check{t} t$ is clearly the basic exponent of the meaning 'to put', Hbr. $\check{s} y t$ is a common but still rather marginal verb in comparison to its ubiquitous synonym sym (85 vs. 582 attestations in the Biblical corpus, Vanoni 2004a:91, 2004b:647). The root $*^{*} \hat{s} y m$, in its turn, is entirely missing from Ugaritic, ${ }^{132}$ which is quite

fornication' (LANE 1369), but, it seems, having šipḥa rather than mišpāḥ̄a in mind (cf. ZoBEL 1998:79). For Zobel, "OSA sfh 'call together' is closer to the mark", but the actual meaning of Sab. and Qat. $s_{1} f$ h seems to be 'to order, to decree, to announce' (JAMME 1962:443, RYCKMANS 1973:383-385, AVANZINI 2004:272, 274), which is not very suggestive for the semantic derivation advocated by Zobel. The common ES root with the meaning 'to be wide, broad' — Gez. safha 'to stretch forth, stretch out, expand, make broad, enlarge' (CDG 487), Tgr. säfha 'to spread, to stretch' (WTS 201), Tna. säfhe 'to be, become wide, broad; grow in extent; to be extensive in length and breadth' (TED 794), Amh. säffa 'to be or become broad' (AED 593), Muh. Sod. säffa, Zwy. säffi 'to be broad' (EDG 537) - could be compared with an underlying meaning shift 'to grow, to expand' > 'family, clan', but if Leslau's comparison between Gez. safha and Akk. sapāhu 'to scatter, disperse' (AHw. 1024, CAD S 151) is correct (HuEHNERGARD 1991a:702), the underlying sibilant must be *s rather than *š. Comparison with Mhr. šfẹh 'to eat food put aside' (ML 392), tentatively proposed in DiAKONOFF-Kogan 2001:105, implies a rather exotic semantic development and is difficult to prove (note, furthermore, that it is unclear whether $\breve{s}$ - in the Mehri verb is part of the root or the causative-reflexive prefix).

${ }^{130}$ V. Buck 1949:833 for Lettish likt 'to put' < PIE *leik ${ }^{w}$ - 'to leave' and DUL 148 for Ugr. ' $d b$ 'to put, place, arrange' < PS * ' $\underline{b} b$ 'to leave'.

131 The meaning 'to leave' for Ugr. $̌ s t$ is indeed registered in DUL, but the only passage where it actually appears in translation is $w \breve{s} t$ ' $i b s n ~ l k m$ 'I leave the warehouse to you' (3.9:5). In view of other attestations of $\breve{s} t+$ direct object $+l(2.41: 18,6.29: 2)$, where this construction is rendered as 'to restore' and 'to set up' in DUL, the translation 'I leave' for $w \check{s} t$ in 3.9:5 is hardly compelling (cf. 'il a réservé son entrepôt pour eux' in BORDREUIL-PARDEE 2004:108). As for 'wrt yštk $b$ l in 1.19 IV 5 , it can be easily rendered as 'may $B$ $l$ make you blind' (for a similar usage of Hbr. šyt v. BDB 1011b). The fundamental semantic difference between the reflexes of PS * šyt in Akkadian and Canaanite ('to leave' vs. 'to put') remains thus obvious.

${ }^{132}$ Note that Pardee reads $h t$ 'at $d b r h m h k m b l<b>k$ 'al tšm 'and you, do not worry about anything' in 2.71:13-15 (instead of $t \check{s} t$ in KTU). 
remarkable in view of its broad presence elsewhere in Semitic. Coexistence of $\check{s y t}$ and sym in Hebrew ${ }^{133}$ as virtual semantic equivalents (Vanoni 2004b:652) is an extraordinary fact which still awaits a proper diachronic assessment. ${ }^{134}$

64. $\boldsymbol{t}^{\text {' }}(\boldsymbol{t}$ ) 'sheath; quiver' (DUL 857).

- Hapax Legomenon in 1.19 IV 44-45: tšt $h[.]$.$b nšgh harb tšt b t^{\prime} r[h]$ 'she puts the [...] into her/its scabbard?, the sword into her/its sheath'. It is uncertain whether the same meaning should be postulated for $t^{\prime} r t$ in 1.18 IV 17-18: 'aštk $k m n \check{s} r b h b[\check{s} y] \mathrm{km}$ d'iy b t'rty 'I will put you like an eagle on' my belt?, like a raptor bird in? my sheath?/quiver"' (cf. Pardee 1997:349).

- Hbr. ta'ar 'sheath' (HALOT 1770-1771).

$\nabla$ The origin of $\mathrm{CC} * \operatorname{ta}^{\prime} r$ - 'sheath' is uncertain. The traditional derivation from * ' $r w$ 'to be naked' (BDB 789) is rejected in HALOT 1770 with no plausible alternative.

65. $t \boldsymbol{k}$ 'centre, middle; in, in the midst of; to, towards' (DUL 867).

- Widely attested (Tropper 2000:772, 775-776).

- Pho. $m t k t$ 'midst' (Krahmalkov 2000:320), ${ }^{135} \mathrm{Hbr} . t \bar{a} w a ̈ k, t \bar{o} k$ 'midst, in the middle' (HALOT 1697). ${ }^{136}$

133 To be sure, also in Phoenician. The Phoenician picture is hard to evaluate because of the scarcity of data, but judging from the examples collected by KraHMALKov (2000:467 and 483484), one can tentatively conclude that, once again, Phoenician is close or identical to Ugaritic and differs from Hebrew: numerous attestations of $\breve{s} t$ contrast sharply with just a handful of examples involving $\check{s} m$ (only one of them pre-Punic).

134 There are good reasons to assume that $* \hat{s} y m$ was the basic verb with the meaning to put' in PS, which, at some early moment of the linguistic history of Common Canaanite, started to be replaced by the innovative *syt. As pointed out by VANONI (2004b:647-648), most of the attestations of $\breve{s} y t$ in Hebrew are early or archaic/archaizing (poetry and pre-exilic prose). It means that early Hebrew was indeed affected by the $* \hat{s} y m>\check{s y t}$ replacememt. The subsequent "revitalization" of sym is, therefore, a bit difficult to conceive as a purely internal process. Rather, one is tempted to attribute this retrograde development to a foreign influence. (Proto-)Aramaic, where * $\hat{s} y m$ is the only basic exponent of the meaning 'to put' since the earliest inscriptions on, is of course a likely source of such an influence. For possible implications of this and similar isoglosses for the lexical aspect of the Mischsprache theory v. Kogan 2006b:251-252.

${ }^{135}$ For this interpretation v. most recently TROPPER 1993:35, 273. The translation 'oppression' accepted in DNWSI 708 is hardly attractive.

${ }^{136}$ As is well known, the functional overlap between Ugr. $t k$ and Hbr. $t \bar{o} k$ is not complete. In Ugaritic, $t k$ is often used with the terminative force, whereas the locative meaning is typical for the combination $b$ tk (TROPPER 2000:772, 775-776). In Hebrew, the combination $b \partial-t \bar{o} k$ clearly predominates and its meaning is locative rather than terminative (BDB 1063-1064). 
$\boldsymbol{\nabla}$ The origin of CC *tawk- 'midst' in uncertain. Comparison with Akk. tikku 'neck' suggested in Watson 1999:791 is unattractive both formally and semantically. A loanword from Hittite tuekka- 'body, self' has been surmised by Rabin (1963:136-137).

66. tmnt 'frame, form' (DUL 872).

- $\quad$ Attested twice in incantations: 1.169:5-6 (tht'a l gbk w trš $l$ tmntk 'that it may harm your body and injure your shape') and 9.435:14-15 ( $l$ 'urtn $l$ gbh $l$ tmnth 'for 'urtn, for his body and his shape'). ${ }^{137}$

- Hbr. təmūnā 'form, manifestation' (HALOT 1746).

$\boldsymbol{\nabla}$ The origin of CC *tamūnat- 'shape, body, form' ${ }^{138}$ is uncertain as no semantically suitable root $* m w n / * m y n$ is at hand (Waschke 2006:687). ${ }^{139}$ The hypothetical relationship with Hbr. min 'type, kind' (HALOT 577, Cazelles 1969), in its turn etymologically obscure, is highly problematic.

67. tšyt 'triumph, success' (DUL 882).

- Hapax Legomenon in 1.3 III 25-27: tydd kbdh b șḥ yml'u lbh b šmht $k b d$ ' $n t$ t $\check{y} y t$ 'her liver swells with laughter, her heart fills with joy, ' $n t$ 's liver with triumph'. ${ }^{140}$

${ }^{137}$ For tmn in 1.2 IV $17-18 \mathrm{v}$. section 2.3 of the second part of this contribution.

${ }_{138}$ Diachronic identity between Ugr. tmnt and Hbr. təmūnā seems to be accepted by most Ugaritologists, but exact semantic details of this identification did not receive enough attention in recent treatments of both relevant texts (PARDEE 2000:884-885, FORD 2002a:147, 2002b:174, contrast Pardee's and Ford's extensive treatment of Ugr. $g b$ - Hbr. gab). As far as I can see, the semantic overlap between Ugr. tmnt and Hbr. təmūna $\bar{a}$ is not exact, since the Hebrew lexeme lacks anatomic connotations.

139 The semantic similarity between tmnt/təmūnā and Tgr. minät 'nature, figure, appearance, shape' (WTS 129) is of course quite striking. In WTS this form is treated as an (irregular, IIy) derivate of mäna 'to create' (IIIy), from which məne 'lie, falsehood' is also thought to be derived. The latter noun, in its turn, is clearly identical to Gez. tamayyana 'to deceive' (CDG 376) and Arb. myn 'to lie' (LA 13 525), both II $y$ as the Hebrew form. However, no other meanings (such as 'to create, to split, to plow') seem to be attested for the Arabic root, contra HALOT 577, FABRY 1997:288, WASCHKE 2006:687: the verb māna 'to split the ground for sowing' (LA 13 525) is obviously derived from the substantive $m \bar{a} n$ - 'hoe' (itself probably not genuine). Tgr. $\min$ in min 'adom 'men, mankind' is (contra LiTTMANN and HöFNER, WTS 741) certainly unrelated to Hbr. min, being rather a deformation of Arb. bin 'ädam with dissimilation (exactly the same development is observable in Mhr. manēdam 'person', ML 267).

${ }^{140}$ As one can infer from Pardee 1988:305, he identifies $t \check{s} t$ in 1.108:20 ( $l$ tštk $l$ 'iršt $[k]$ 'à ton succès, à ta requête') with Ugr. tšyt and Hbr. tūšiyyā (cf. DUL 882 and DEL OLMO LeTE 2004:189). 
- Hbr. $t \bar{u} s ̌ i y y \bar{a}$ 'success, good result; sound wisdom, prudence' (HALOT 1713).

$\boldsymbol{\nabla}$ The origin of CC *tūšiyy-at- 'success' is uncertain. ${ }^{141}$

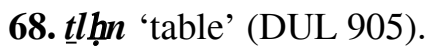

- Widely attested, the meaning 'dining table' is clear from 1.4 IV 35-37

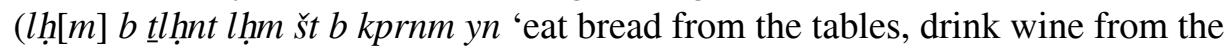
goblets').

- Hbr. šulhān 'table' (HALOT 1519).

v The origin of CC *tulhān- 'table' (Greenfield 1969:98, Ginsberg 1970:103) is uncertain. As duly recognized in Blau 1956:243 and HALOT 15191520, the Ugaritic form with $\underline{t}$ and $h$ makes unattractive the traditional identifications of Hbr. šulhān with either *šlḥ 'to send, to stretch out' (Akk. šalāh̆u, Ugr. šlh, Hdr. $s_{1} l h$, CAD Š $\breve{S}_{1} 193$, DUL 816, Pirenne 1990:107) or *šlh 'to strip off (hide)', *š Vlh- 'hide, skin' (Syr. šelḥ̄a, Arb. salh-, SED I No. 244). ${ }^{142}$

69. $\underline{t} \boldsymbol{c}$ " to be frightened, scared' (DUL 935).

- Reliably attested in 1.6 VI 30 and 1.5 II 7 (both analyzed under No. 76 in this section).

- Pho. $\breve{s} t^{\prime}$ in $b m k m m$ 'š $k n$ lpnm nšt' 'm 'š yšt' 'dm llkt drk 'in the places which used to be fearful, where people were afraid to walk on a road' (KAI 26A II 3-5, DNWSI 1199), Hbr. 'al tišta' 'do not be afraid' (Is 41:10), ništz 'a 'let us be afraid' (Is 41:23). ${ }^{143}$.

$\boldsymbol{\nabla}$ The origin of CC * $\underline{t} t^{c}$ 'to be afraid' (Greenfield 1969:99) is uncertain. Comparison with Arb. $\check{s} t$ ' 'to be sad, worried because of hunger or disease' (LA 8 206), accepted in DUL 935 and elsewhere, is problematic both phonetically and semantically, let alone the exceedingly marginal status of the Arabic verb (cf. HALOT 1671). Since $t-t$ is an unwelcome sequence of root consonants, $-t$ - is likely a fossilized reflexive infix. Are we faced with a $t$-derivate from $* t t^{\prime} y$ 'to gaze, to look at, to seek', represented by Akk. $\check{s} e$ ' $\hat{u}\left(\mathrm{CAD} \breve{S}_{2} 355\right)$ and $\mathrm{Hbr}$. $\check{s} \bar{a}$ ' $\bar{a}$ (HALOT 1609)? The underlying semantic shift 'to look around' > 'to be

141 The Ugaritic form with $\check{s}$ evidently precludes any comparison with Hbr. yěs 'there is' (< *ytw), still often postulated in Biblical studies (cf. GerTz 2006:647).

142 So BDB 1020, Tropper 2000:109. 228).

143 In both attestations paralleled by $y r$ ' 'to be afraid' (HALOT 1671, GREENFIELD 1958:226- 
frightened' seems possible, ${ }^{144}$ but hardly self-evident. Besides, there is no proof that it is indeed $* \underline{t}$ that is behind $\check{s}$ in either Akkadian or Hebrew. Sab. $t \underline{t} t$, compared in Tomback 1978:335, is translated as 'slander, calumny' in SD 149 '145 and can thus hardly be relevant.

70. $\boldsymbol{w s r}$ 'to teach, to instruct' (DUL 943).

- The meaning 'to teach' is likely in both contexts where wsr is attested: rbt 'ilm l ḥkmt šbt dḳnk l tsrk 'you are great, oh 'il, you are wise! your grey beard surely instructs you!' (1.4 V 3-4) and 'ap yṣb yt b hkl w ywsrnn ggnh 'also Yṣb sat in (his) palace and his inwards instructed him' (1.16 VI 25-26). ${ }^{146}$

- Hbr. ysr 'to instruct' (HALOT 418).

$\boldsymbol{\nabla}$ The origin of CC *wsr /*ysr 'to teach, to instruct' is obscure.

71. $\boldsymbol{y} \boldsymbol{r}$ 'razor' (DUL 947).

- Hapax Legomenon in 1.5 VI 17-18 ( $\gamma r b$ 'abn ydy psltm $\left.b y^{\prime} r\right)$. The meaning 'razor' fits the context and is generally accepted (e. g. 'with a stone he scratches incisions on (his) skin, with a razor he cuts cheeks and chin' in Pardee 1997:268).

- Hbr. ta 'ar 'knife, razor' (BDB 789, HALOT 1770).

$\boldsymbol{\nabla}$ The origin of $\mathrm{CC} * y a^{\prime} r$-/*ta ' $r$ - 'knife, razor' remains uncertain, although the traditional derivation from * ' $r w$ 'to be naked', accepted in BDB 788-789 and Aistleitner 1963:242, but rejected as "clearly not relevant" in HALOT 1770, is still attractive, especially if the term denoted specifically a shaving razor (i. e., "an instrument making the skin bare" ${ }^{147}$ ).

72. $\boldsymbol{y n}$ 'wine' (DUL 968).

- Passim throughout the Ugaritic corpus.

- Old Canaanite ye-nu (Rainey 1976:137), ${ }^{148}$ Pho. yn, Amm. yn (DNWSI 455), Hbr. yayin (HALOT 409).

${ }^{144}$ Cf. especially Akk. šite' $\hat{u}$ 'to look all over, to strive for, to be assiduous, to be solicitous' (CAD $\left.\breve{S}_{2} 355\right)$.

145 Contrast Tomback's 'fear'.

146 A nearly exact parallel is found in Ps 16:7 (yissarūnī kilyōtāy 'my reins instructed me').

${ }^{147}$ Cf. Ukrainian голитися 'to shave' < голий 'bare, naked'.

${ }^{148}$ In the trilingual lexical fragment from Tel Aphek (= Sum. [GEŠTIN.]MEŠ, Akk. ka-ra$n u$ ). It is uncertain whether $i$-nu, equated to Sum. MU.TIN in CT $191 \mathrm{~d}: 10$, represents a Canaanite loanword with the meaning 'wine' (cf. AHw. 383, CAD I 152 as well as RuBIo 1999:8). 
$\boldsymbol{\nabla}$ CC *yayn- 'wine' goes back to PWS *wayn- which, judging by the meaning of the Arabic, ESA and ES cognates, probably denoted 'vine(yard)' (Sab. and Qat. wyn, SD 166, LIQ 51, Gez. wayn, CDG 623, LLA 928-929, Sima 2000:250-257) or 'grapes' (Arb. wayn-, LA 13 563, cf. Rabin 1963:138, Sima 2000:256) rather than 'wine'. ${ }^{149}$ The exclusively Canaanite nature of this lexeme ${ }^{150}$ is undermined by the fact that the reflex of PWS *wayn- as the main designation of wine is attested also in Geez. ${ }^{151}$

73. $\boldsymbol{y} \mathbf{k} \check{s}$ 'fowler, bird-catcher' (DUL 976).

- Attested in lists of people by profession ( $y k$ šm 'fowlers' in 4.99:6, 4.126:25), the meaning being thus derived from etymology. The same is true of the syllabic ${ }^{\text {Lú } i a-k ̣ i-s ̌[u] ~(H u e h n e r g a r d ~ 1987: 134) . ~}$

- Hbr. $y k \grave{s}$ 'to catch a bird with a snare', yāḳ̄šs 'fowler', mōḳ̄ěs 'snare' (HALOT 432, 430, 561). Also related are $n k \grave{s}$ 'to become ensnared' (HALOT 723 ) and $k w \check{s}$ 'to trap with a snare' (HALOT 1091).

$\nabla$ The origin of $\mathrm{CC} * y k \grave{s}$ 'to hunt with a snare' is uncertain. Comparison with Gez. wak $a \hat{s} a$ 'to reprimand, to reproach' and related ES forms suggested in CDG $616^{152}$ is semantically far-fetched. The Ugaritic form should prevent one

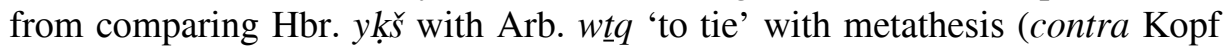
1976:150-151). ${ }^{153}$

74. $\boldsymbol{y} \boldsymbol{p h}$ 'witness' (DUL 974).

- Widely attested in contracts and economic documents and, as rightly acknowledged in Pardee 1978:206, almost certainly the main exponent of the meaning 'witness' in Ugaritic.

149 This conjecture becomes especially attractive if PWS * wayn- is considered to be borrowed from an Indo-European source, since the meaning 'vine' in PIE can be plausibly derived from the verbal root *wei- 'to twist, to wind' (Buck 1949:390, cf. Fronzaroli 1971:613-614, Sima 2000:255-256 with further references).

150 Note in particular the absence of *yayn- 'wine' from Aramaic, where this meaning is commonly expressed by *hamr- since Official Aramaic on (KogAN 2005:551-552, cf. HALOT 1877). The presence of $y n$ 'wine' in the account document RÉS 1791 (PORTEN-YARDENI 1993:74) is likely due to Hebrew influence.

${ }^{151}$ For the earliest Geez attestations v. Sima 2000:256.

152 "The Ethiopic root has a figurative meaning in relation to Semitic "lay snares". Cf. also DRS 613.

${ }^{153}$ As pointed out above, Kopf is admittedly correct to emphasize that the meaning of the Ugaritic noun seems to be entirely dependent on the Hebrew etymology. 
- Hbr. yāpēaḥ ‘witness' (HALOT 424), ${ }^{154}$ yāpīaḥ id. (Pardee 1978:206210, cf. HALOT 917). ${ }^{155}$

$\nabla$ No convincing etymology for CC *yapụh- 'witness' has been suggested so far (cf. Pardee 1978:210-212).

75. yr 'early rain' (DUL 977).

- Reliably attested in 1.19 I 39-42 (yṣly 'rpt b ḥm 'un yr 'rpt' tmț b kțțl $y$ tll $l \mathrm{rnbm}$ 'he implores the clouds in the terrible draught, the rain which the clouds pour down in summer, the dew which falls on the grapes') and 1.14 II 39-40 ( $h l k l$ 'alpm $h \underline{d} \underline{d} \underline{d} w l$ rbt $k m$ yr 'they went in thousands like a downpour, in myriads like an early rain').

- Hbr. yōrä 'early rain’ (HALOT 404).

$\boldsymbol{\nabla}$ The origin of CC *ya riy- is uncertain, but it is tempting to surmise (with DRS 621-622) a connection with the widely attested verbal root *rwy 'to be saturated with water' (for which v. HALOT 1194-1195 and CDG 478).

76. $y \boldsymbol{r}$ ' 'to be afraid' (DUL 977).

- Possible attestations of this root are discussed in Tropper 1996, who deals extensively with both relevant passages: 1.5 II 6-7 (yr'a'un ${ }^{156}$ 'al'iyn $b^{\prime} l$ $\underline{t} t^{\prime} n n r k b$ ' $r p t$ 'the mighty $B$ ' $l$ feared him, the Rider of the clouds was frightened of him') and 1.6 VI 30-32 (yr'u bn 'ilm <m>t $\underline{t} t^{\prime} y d d$ ' $i l \quad \gamma z r$ 'Mt, the son of 'il was afraid, frightened was the beloved son of 'il, the warrior').

- Hbr. $y r$ ' 'to fear' (HALOT 433).

$\boldsymbol{\nabla}$ There is no immediate etymological parallel to CC * $y r$ ' 'to be afraid', which, at least in Hebrew, has become the basic verb with this meaning. Hypothetic cognates (DRS 483, 615-616) involve either metathesis (Arb. w'r 'to

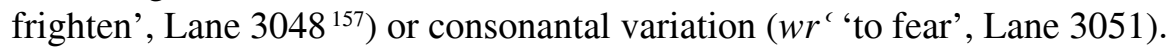

77. $y$ șk 'to pour out; to smelt, cast' (DUL 987).

${ }^{154}$ Hapax Legomenon in Ps 27:12, meaning reliably established from parallelism with $\breve{a} d \bar{e}$ 'witnesses'.

${ }^{155}$ Several reliable attestations in Proverbs.

${ }^{156}$ Exact morphological interpretation of this difficult form is highly problematic, but its attribution to $y r$ ' 'to be afraid' is beyond doubt.

${ }^{157}$ Comparison with Tgr. wära 'to threaten' (WTS 435) in HALOT 432 is problematic since ' is not expected to be lost in Tigre. 
- Both the general meaning 'to pour' and the more technical 'to cast (metals)' are reliably attested: $y s \underline{k} b \mathrm{gl} h \mathrm{ht} \underline{\mathrm{t}} \mathrm{yn}$ 'he poured wine into a silver cup' (1.14 IV 1), yșk ksp l'alpm hrș yṣk l rbbt 'he poured silver into thousands (of shekels), gold into myriads' (1.4 I 26-28).

- Pho. yṣk 'statue' (Tomback 1978:128, cf. DNWSI 466), 'to cast a metal object' (Krahmalkov 2000:214), Hbr. yṣk 'to pour out; to cast' (HALOT 428).

$\boldsymbol{\nabla}$ The origin of CC *yșk 'to pour; to cast' is uncertain.

78. $y \underline{t} \boldsymbol{n}$ 'to be old, become old, wear out', $y \underline{t} n$ 'old, rancid' (DUL 996).

- The meaning 'old' is reliably deduced from 4.168:5-8 (mlbš trmnm $k$ $y \underline{t n} w b$ bt mlk mlbš ytn lhm 'since the garment of trmnm grew old, let one give them one garment from the king's house'). The expression dblt ytht $w$ șm $k m$ ytnm in the hippiatric prescriptions (1.71:27, also 1.72:37-38 and 1.85:31) is

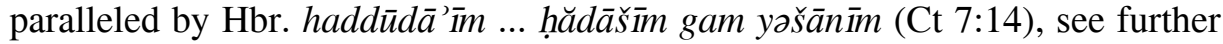
Cohen-Sivan 1983:41.

- Hbr. yšn 'to grow old', yāšān 'old' (HALOT 448).

$\boldsymbol{\nabla}$ The origin of CC * $y \underline{t n}$ 'to wear out, grow old' (Ginsberg 1970:103) is uncertain. Comparison with Arb. 'sn 'to be altered, long standing, rancid (water)' (Lane 60) and snn IV 'to be advanced in age' (Lane 1436) suggested in Tropper 2000:109, albeit semantically attractive, is undermined by the irregular phonological correspondence. ${ }^{158}$ DRS 658 compares Arb. thn IV 'to become wasted and worn out (an old man)', tinn- 'dry herbage' (Lane 356). Cf. also Arb. wtn X 'to become numerous, abundant' (LA 13 547)."

Recibido: 30/06/2009

Aceptado: 20/02/2010

158 See comments on $n \underline{t} \underline{k}$ 'weapons' in No. 48 above in this section.

* Full bibliographical references are provided at the end of «Genealogical Position of Ugaritic... Lexical Isoglosses Between Ugaritic and Other Semitic Languages. Conclusions», to appear in the forthcoming issue of Sefarad. 